\title{
Jasmonates: Multifunctional Roles in Stress Tolerance
}

\begin{abstract}
Parvaiz Ahmad 1,2*, Saiema Rasool'3, Alvina Gul'4, Subzar A. Sheikh ${ }^{5}$, Nudrat A. Akram, Muhammad Ashraf,, 7 , A. M. Kazi ${ }^{8}$ and Salih Gucel ${ }^{9}$

${ }^{1}$ Department of Botany, S.P. College, Srinagar, India, ${ }^{2}$ Department of Botany and Microbiology, College of Sciences, King Saud University, Riyadh, Saudi Arabia, ${ }^{3}$ Forest Biotech Lab, Department of Forest Management, Faculty of Forestry, Universiti Putra Malaysia, Selangor, Malaysia, ${ }^{4}$ Atta-ur-Rahman School of Applied Biosciences, National University of Science and Technology, Islamabad, Pakistan, ${ }^{5}$ Department of Botany, Govt. Degree College (Boys), Anantnag, Anantnag, India, ${ }^{6}$ Department of Botany, GC University Faisalabad, Faisalabad, Pakistan, ${ }^{7}$ Pakistan Science Foundation, Islamabad, Pakistan, ${ }^{8}$ Department of Botany, University of Sargodha, Sargodha, Pakistan, ${ }^{9}$ Centre for Environmental Research, Near East University, Nicosia, Cyprus
\end{abstract}

Jasmonates (JAs) [Jasmonic acid (JA) and methyl jasmonates (MeJAs)] are known to take part in various physiological processes. Exogenous application of JAs so far tested on different plants under abiotic stresses particularly salinity, drought, and temperature (low/high) conditions have proved effective in improving plant stress tolerance. However, its extent of effectiveness entirely depends on the type of plant species tested or its concentration. The effects of introgression or silencing of different JA- and Me-JArelated genes have been summarized in this review, which have shown a substantial role in improving crop yield and quality in different plants under stress or non-stress conditions. Regulation of JAs synthesis is impaired in stressed as well as unstressed plant cells/tissues, which is believed to be associated with a variety of metabolic events including signal transduction. Although, mitogen activated protein kinases (MAPKs) are important components of JA signaling and biosynthesis pathways, nitric oxide, ROS, calcium, ABA, ethylene, and salicylic acid are also important mediators of plant growth and development during JA signal transduction and synthesis. The exploration of other signaling molecules can be beneficial to examine the details of underlying molecular mechanisms of JA signal transduction. Much work is to be done in near future to find the proper answers of the questions like action of JA related metabolites, and identification of universal JA receptors etc. Complete signaling pathways involving MAPKs, CDPK, TGA, SIPK, WIPK, and WRKY transcription factors are yet to be investigated to understand the complete mechanism of action of JAs.

Keywords: jasmonate biosynthesis, MAPK cascades, physiological responses, plant stress tolerance, signaling pathway

\section{INTRODUCTION}

Plants being sessile can respond to environmental cues through a variety of physio-biochemical processes and structural modifications (Ahmad et al., 2008; Farrant and Ruelland, 2015). Plants produce volatile and non-volatile compounds including phytohormones that help them to adapt to changing environment (Bari and Jones, 2009; Ashraf et al., 2010; Javid et al., 2011). Phytohormones have a leading role in various physiological and developmental processes in plants (Rohwer and Erwin, 2008; Ashraf et al., 2010; Kumar et al., 2014). An important phytohormone, JA (jasmonic 
acid) and its methyl ester, methyl jasmonates (MeJAs), are derivatives of the fatty acid metabolism (Kupper et al., 2009; Gao et al., 2011; Jalalpour et al., 2014). JA is ubiquitously found in the plant kingdom (Schaller, 2011; Pirbalouti et al., 2014). Jasmine (Jasminum grandiflorum) oil is used as a primary source to isolate MeJA (Avanci et al., 2010). JA was isolated for the first time from the culture of fungus Lasiodiplodia theobromae which is an important member of the JAs (Tsukada et al., 2010). Apart from JA and MeJA, other JAs particularly cisjasmone, jasmonoyl ACC (JA-ACC), and jasmonoyl isoleucine (JA-Ile) with multiple biological functions have been reported (Rohwer and Erwin, 2008; Avanci et al., 2010; Wasternack and Kombrink, 2010; Koo and Howe, 2012). Tuberonic acid (TA) and its glucoside (TAG) were found in the leaves of Solanum tuberosum (Wakuta et al., 2010; Seto et al., 2011), which were believed to be involved in tuber formation. In various plant species, these compounds can be biosynthesized by hydroxylation and subsequent glycosylation (Wakuta et al., 2010). Cucurbic acid, a compound similar to JA, identified in the seeds of Cucurbita pepo (Nam and Yoshihara, 2008), was reported to be actively involved in tuberization (Honda et al., 2006). JA and MeJA analogs with physiological activities have also been reported (Kazan and Manners, 2008, 2011; Baenas et al., 2014). For example, Kondo et al. (2000) reported an increase in the $\mathrm{ABA}$ and anthocyanin contents in apples through PDG ( $N$-propyl dihydrojasmonate). Coronatine isolated from Pseudomonas syringae is a phytotoxin and is the most active isomer of JA. It has been reported to be involved in alkaloid accumulation in Eschscholzia californica, tendril coiling in Bryonia dioica, and tuber cell expansion in Solanum tuberosum (Koda, 1997; Rohwer and Erwin, 2008).

Jasmonate and MeJA are believed to play an active role in senescence. In addition, a variety of JA-induced plant growth, developmental and physiological activities have been reported including fertility, biotic and abiotic stress tolerance, sex determination, storage organ formation, reproductive processes, root elongation, fruit ripening and senescence, oxidative defense, and interaction with other hormones (Browse, 2009; Moreno et al., 2009; Avanci et al., 2010; Cipollini, 2010; Nafie et al., 2011). Other physiological functions related to the JA are stimulation of germination in dormant seeds (Creelman and Mullet, 1997), accumulation of storage proteins (Pelacho and Mingo-Castel, 1991), chlorosis (Creelman and Mullet, 1997), upregulation of antioxidant enzymes (Soares et al., 2010), senescence (Seltmann et al., 2010), floral nectar synthesis (Radhika et al., 2010a,b), herbivory and wounding (Chung et al., 2008; Howe and Jander, 2008; Ballare, 2011; Erb et al., 2012), seed and flower development (Wasternack et al., 2012), systemic resistance (Pieterse et al., 2002, 2012), elicitors of plant secondary metabolism (De Geyter et al., 2012), and allelopathy (Baldwin, 2010), etc. Its role in gene expression has been reported in different plants such as grapevines (Marchive et al., 2013), Arabidopsis (Sasaki et al., 2001), tomato (Boter et al., 2004), rice (Schweizer et al., 1997; Liu et al., 2012), sugarcane (De Rosa et al., 2005), etc., which leads to defense against environmental stresses (Gfeller et al., 2010b; Ballare, 2011; Sua et al., 2011).
In plants, the concentration of JAs ranges from 0.01 to $3.0 \mathrm{ng} / \mathrm{g}$ FW (fresh weight) with the exception of Artemisia tridentata in which MeJA level up to $95 \mu \mathrm{g} \mathrm{g}^{-1}$ fresh weight has been recorded (Preston et al., 2004). JA has been found in abundance generally in flowers and chloroplasts of illuminated plants (Creelman and Mullet, 1997; Yan et al., 2013).

Research on JA signaling is gaining ground day by day, because of the primary reason that they are involved in regulation of tolerance against different environmental stresses (Fonseca et al., 2009; Koo et al., 2009; Gfeller et al., 2010a; Wasternack and Hause, 2013) as well as their integration with the signaling pathways generated by salicylic acid, ABA, ethylene, and other such molecules. In fact, most of the information on JA signaling has been derived from studies on two widely researched plants Arabidopsis and tomato (Turner et al., 2002; Browse and Howe, 2008). One could expect considerable variation among JA signaling pathways operative in other species with complex genomes exposed to different stresses. Thus, the present review focuses on elucidation of the role of JAs in various physiological and molecular processes involved in stress tolerance, as well as it offers important details about the signaling pathways in plant stress tolerance mechanisms.

\section{JASMONATE BIOSYNTHESIS}

Jasmonic acid biosynthetic pathway was first described by Vick and Zimmerman (1984), and since then it has been thoroughly studied in Arabidopsis and tomato. JAs and MeJA are produced from $\alpha$-linolinic acid $(\alpha$-LeA) localized in chloroplast membranes (Wasternack and Kombrink, 2010). The formation of $\alpha$-LeA from lipids occurs through the action of phospholipases. An intermediate compound 13-hydroperoxy$9,11,15$-octadecatrienoic acid (13-HPOT) is formed by the addition of oxygen molecule to $\alpha$-LeA and the reaction is stimulated by 13-lipoxygenase (LOX). This 13-HPOT is then oxidized to allene oxide by allene oxide synthase (AOS). Allene oxide is an unstable compound which is then converted to 12oxo phytodienoic acid (12-OPDA) by the enzyme allene oxide cyclase (AOC). The AOS and AOC are present in plastids and they act in concert (Schaller and Stintzi, 2009; Gfeller et al., 2010b; Wasternack and Hause, 2013). The enzyme AOS belongs to the cytochrome P450 family, a potential catalyst for JA biosynthesis (Schaller and Stintzi, 2009). The final product of metabolic pathway of JA biosynthesis is 12-OPDA which occurs in the chloroplast which undergoes three cycles of $\beta$-oxidation in the peroxisomes (Delker et al., 2006; Wasternack, 2007; Bussell et al., 2013). Figure 1 clearly shows the JA formation from 12-OPDA with different metabolic conversions forming distinct JAs. MeJA is formed by the methylation reaction in the presence of JA methyltransferase. It has been reported that AOC is encoded by one gene in tomato but by a gene family (small) in Arabidopsis (Wasternack and Hause, 2013). Some cDNA studies have shown that AOS is a protein having C-terminal domain identical to cytochrome P450s containing heme-binding cysteine and is composed of about 536 amino acids (Schaller and Stintzi, 2009). It is not clear as to how 




12OPDA enters in peroxisomes, wherein final steps of JA synthesis take place. However, some complex and contrasting reports on this process are available. Thus, it still needs to be elucidated that how the JAs production is regulated initially and its synthesis is limited particularly in stressed plant cells/tissues.

\section{EXOGENOUS APPLICATION OF JASMONATES AND PLANT STRESS TOLERANCE}

Under environmental stresses (biotic and abiotic), plants show a wide range of responses from synthesis of signaling compounds to eventual cell death (Avanci et al., 2010; Table 1; Figure 2). Environmental stresses induce the synthesis of different plant hormones (Figure 2). These phytohormones are required at various developmental stages of the plants and help in their defense responses (Ashraf et al., 2010; Denancé et al., 2013). Rosahl and Feussner (2005) demonstrated that JAs and their derivatives regulate the gene expression involved in defense responses. JA dependent defense responses are activated as a result of necrotrophic pathogen infection (Trusov et al., 2006; Avanci et al., 2010).

Jasmonate treated plants have been found to show enhanced resistance against pests. Tomato plants treated with JA have shown reduced number of Frankliniella occidentalis (thrips), flea beetles and aphids, which were ascribed to an increase in the activities of polyphenol oxidase and proteinase inhibitors (Thaler et al., 2001). The expression of defense-related enzymes mainly lipoxigenase and peroxidase followed by polyphenol oxidase were significantly higher in plants damaged by ventral eversible gland intact (VEGI) caterpillars than that in plants damaged by ventral eversible gland ablated (VEGA) caterpillars. They observed that the genes encoding these enzymes were also involved in the biosynthesis of JA and terpene synthase genes, and subsequently, involved in the regulation of terpenes (Zebelo et al., 2014). JAs are also involved in the resistance to root pests like fungus gnat (Bradysia impatiens) as studied in Arabidopsis (McConn et al., 1997) and spinach (Schmelz et al., 2002). They suggested that the mutant will be a good genetic model for testing the practical effectiveness of defensive genes as they observed that exogenous application of MeJA significantly reduced mortality to $\approx 12 \%$ and protected the mutant plants. Thus, plants are equipped with sophisticated defense systems to protect themselves against the attack of herbivorous organisms (Ballare, 2011).

It has been observed that the sorbitol treated barley leaves showed enhancement in JA and JA-induced protein levels (Rohwer and Erwin, 2008), proving the role of JAs in osmotic stress. JAs are found to regulate the stomatal apertures (Hossain et al., 2011; Riemann et al., 2015). Exogenous JA (50 $\mathrm{mmol} \mathrm{m}^{-3}$ ) application causes an increase in glycine betaine levels, activity of $\mathrm{BADH}$ enzyme as well as level of $\mathrm{BADH}$ protein in grafted Pyrus bretschneideri Redh subjected to water deficit conditions (Gao et al., 2004).

Reactive oxygen species (ROS) are very harmful for the growth and development of most organisms as these can affect the structure and function of biomolecules (Ahmad et al., 2008, 2010, 2011a,b,c; Koyro et al., 2011; Akram et al., 2012; Akram and Ashraf, 2013; Shafiq et al., 2014). The ROS include $\mathrm{H}_{2} \mathrm{O}_{2}$, $\mathrm{O}_{2}{ }^{-}$, and ${ }^{\bullet} \mathrm{OH}$ (Faurie et al., 2009; Akram et al., 2012). Soares et al. (2010) have demonstrated a gradual accumulation of $\mathrm{H}_{2} \mathrm{O}_{2}$ in Ricinus communis between 1 and $6 \mathrm{~h}$ after treatment with 


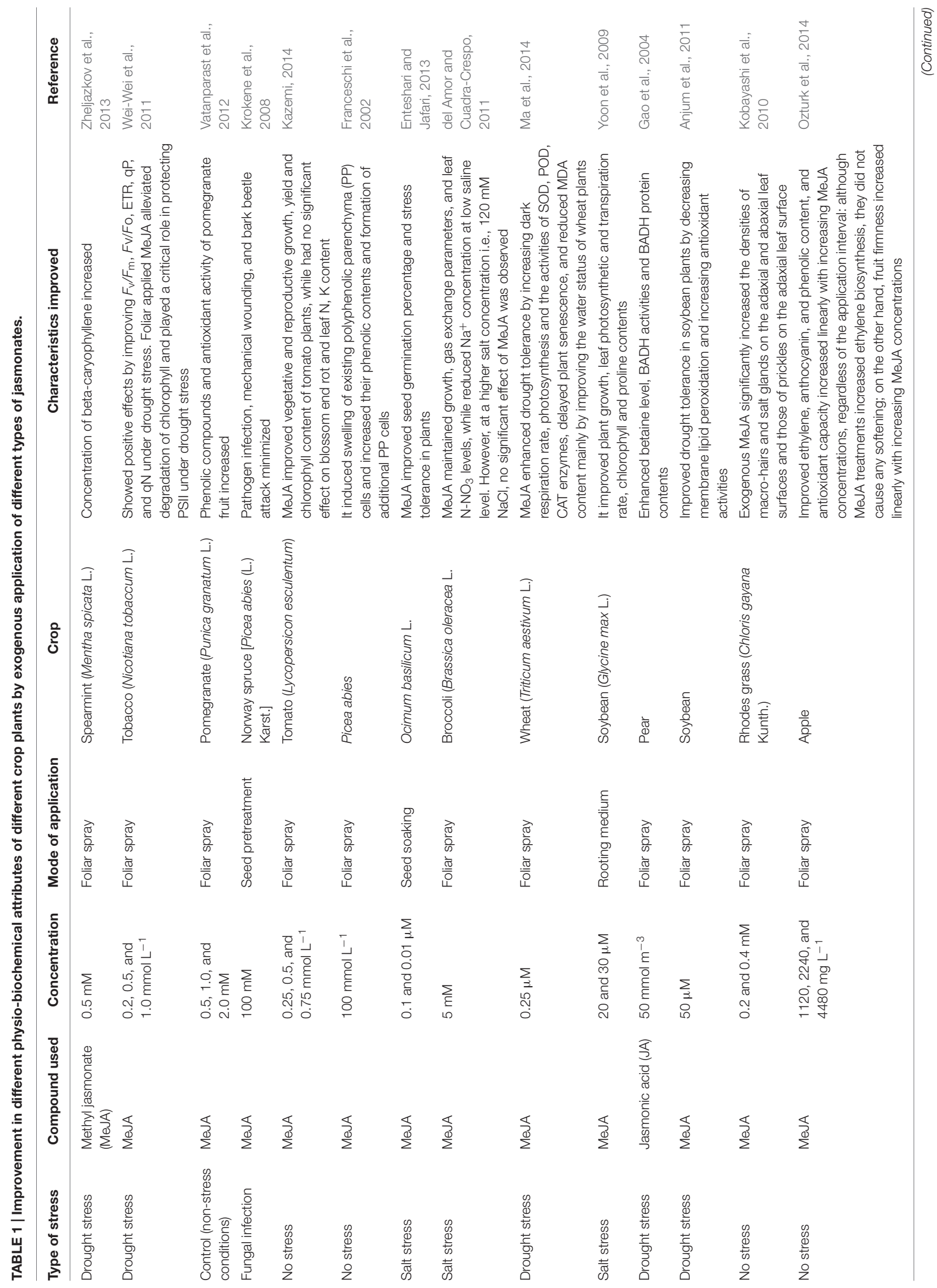




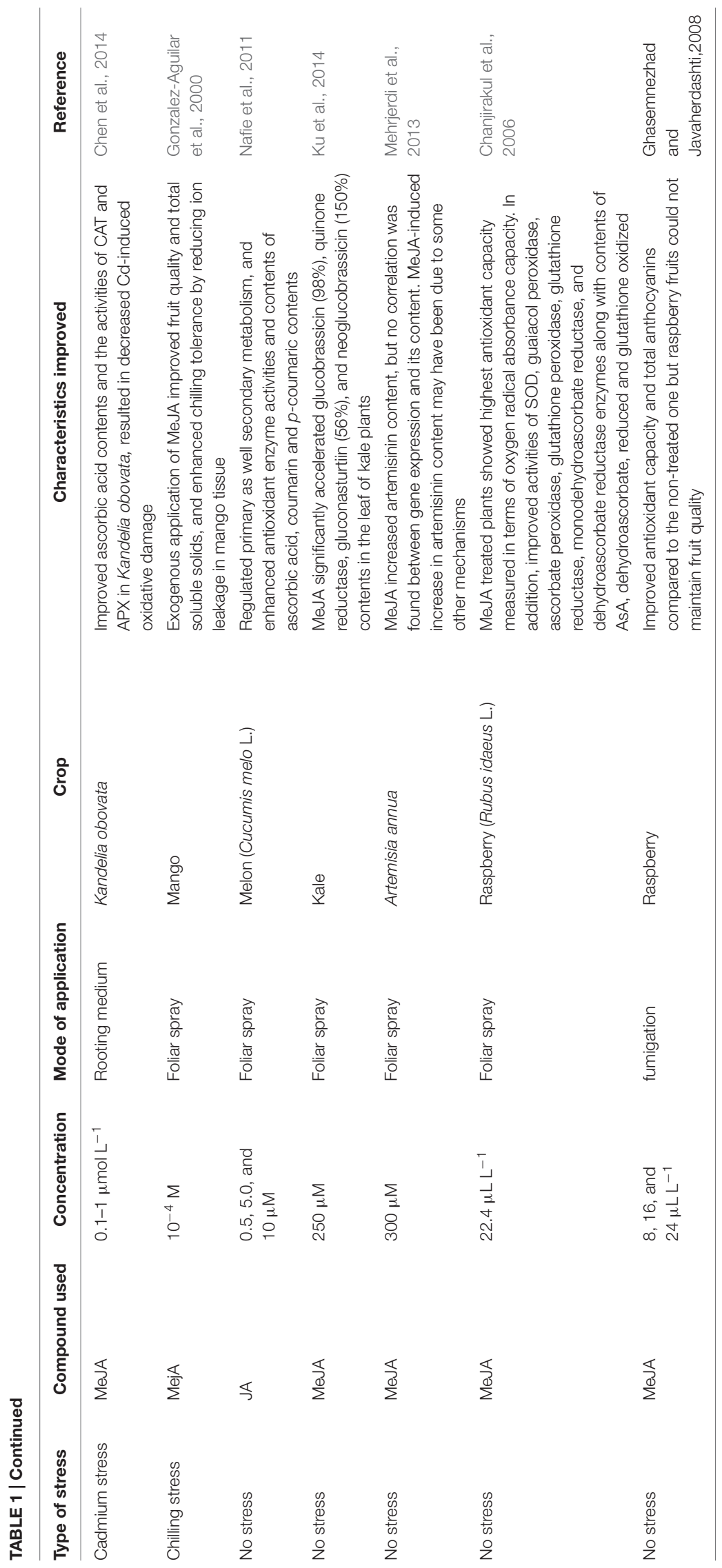




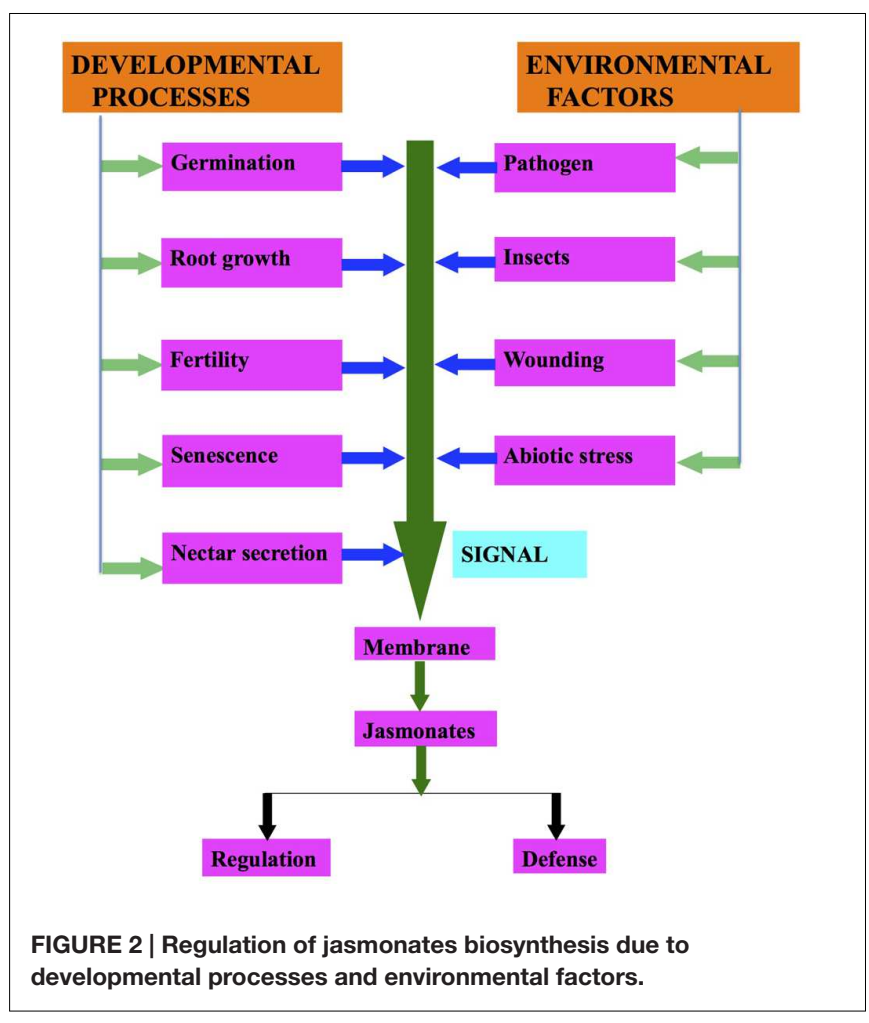

MeJA. They also observed a sharp formation of ROS at the initial moment of MeJA application and ascribed it to the decrease in the activities of enzymatic antioxidants. In another study with pomegranate (Punica granatum L.), Vatanparast et al. (2012) observed an increase in phenolic compounds and antioxidant activity in the foliage treated with $0.5-2.0 \mathrm{mM} \mathrm{MeJA}$. Orvar et al. (1997) demonstrated that pre-treatment of tobacco plants with JA inhibited ozone induced cell death. They found that after 3$4 \mathrm{~h}$ of MeJA application the activity of ascorbate peroxidase was upregulated while that of carbonic anhydrase mRNA decreased in tobacco plants subjected to ozone treatments. JA reduced the amount of SA produced in response to $\mathrm{O}_{3}$ in Arabidopsis (Rao et al., 2000). MeJA reduced the adverse effects of drought and oxidative stresses in strawberry (Wang, 1999). Pre-treatment of barley seeds with MeJA showed less membrane damage than did the non-treated plants (Bandurska and Stroiński, 2003).

Methyl jasmonate application enhanced the amount of ascorbic acid in Arabidopsis and tobacco suspension cells (Wolucka et al., 2005) and influences the metabolism of AsA (Maksymiec and Krupa, 2002; Wolucka et al., 2005). AsA is a very important antioxidant, which protects the plants under oxidative stress (Ahmad et al., 2011a,b,c; Shafiq et al., 2014). It has been reported that exogenous application of JA increases AsA in different plants suggesting that JA may regulate AsA metabolism (Ayala-Zavala et al., 2008; Chen et al., 2014). Grantz et al. (1995) reported that AsA increased due to wounding and it led to improved stress resistance. Likewise, Suza et al. (2010) also demonstrated enhanced accumulation of AsA Arabidopsis by wounding.
In Table 1, it has been summarized that how exogenous application of JAs regulates a number of processes in different plants on exposure to different environmental stresses. JA has been reported to protect Zucchini from chilling injury (Wang and Buta, 1994). Exogenous application of MeJA improved fruit quality and enhanced chilling stress tolerance of mango (Mangifera indica) fruit without affecting fruit ripening process (Gonzalez-Aguilar et al., 2000). Droby et al. (1999) have reported that application of MeJA suppresses the fungal growth in grapefruit. Moreover, MeJA maintained the post-harvest quality of papayas (Gonzalez-Aguilar et al., 2003). MeJA enhanced the antioxidant system and the free radical scavenging capability of raspberry fruits plants making them more resistant to decay (Ghasemnezhad and Javaherdashti, 2008; Wang et al., 2009). External application of JAs also improves fruit quality, which is believed to be associated with a variety of metabolic events including signal transduction. Nitric oxide, ROS, calcium, ABA, ethylene, and salicylic acid are also important mediators of plant growth and development during JA signal transduction and synthesis.

\section{JAMONATES AND PHYSIOLOGICAL RESPONSES}

The first physiological effect demonstrated for JA was root growth inhibition (Adams and Turner, 2010; Liu et al., 2010). Coi1, Jin1, or Jar1 are JA-insensitive mutants and did not show any effect on root length during JA treatment and the root length was similar as compared to untreated wild-type (WT). JA-sensitive mutants like Cex1, Cet1, Cev1, and Joe2 were characterized by stunted growth and suppressed root length. They exhibit overexpression of JAinduced genes (Pauwels et al., 2009).

Jasmonate and MeJA stimulated the germination of dormant seeds (Norastehnia et al., 2007; Dave et al., 2011) and it was observed that increase in JAs causes lipid peroxidation, which in turn causes membrane damage, hence resulting in enhanced germination (Ranjan and Lewak, 1992). In soybean plant, organs like hypocotyl hook, axes, and plumules showed higher levels of JA as compared to the hypocotyl zone of elongated cells and the non-elongating roots and stems (Creelman and Mullet, 1995). JA was first seen in Solanaceae species and recently in Arabidopsis thaliana (Gidda et al., 2003). In A. thaliana it is recognized as a substrate for AtST2a (sulfotransferase). AtST2a helps reduce the endogenous levels of 12-OH-JA, a hydroxylated product of JA (Gidda et al., 2003; Faraz, 2006; reviewed by Wasternack, 2007).

Staswick (1994) demonstrated that JA regulates the genes of vegetative storage proteins (VSPs). VSPs have been characterized and purified for the first time from soybean plant (Wittenbach, 1983). VSPs localize themselves in vacuoles and bundle sheath cells of soybean (Franceschi et al., 1983). Staswick (1989) demonstrated that accumulation of VSPs occurs in pods and developing reproductive parts excluding seeds, so it can be suggested that the VSPs are temporary deposits of amino acids obtained from disassembly of leaf proteins and Rubisco, that become active for seed formation. JA along with sugars, 
phosphate, nitrogen and auxin regulate these proteins (Creelman and Mullet, 1997). A. thaliana AtVSPs and soybean VSPs show high levels of expression in developing fruit as well as flowers (Bell et al., 1995). In Coil mutant (insensitive to JA) of $A$. thaliana, the AtVSP proteins in flowers were absent and can be induced upon JA treatment (Benedetti et al., 1995). Deficient in JA Arabidopsis mutants like dad 1 and opr3 showed reduced filament elongation associated with low accumulation of JA in the filaments of the double mutant arf6/arf8. These mutants are unable to produce two ARFs (auxin response factors) involved in filament elongation, which showed that auxin signaling is interlinked with JA (Wasternack, 2007).

Nodule is a bulbous root structure found in leguminous plants. It contains a bacterial enzyme nitrogenase, which is responsible for the fixation of atmospheric nitrogen. According to Stougaard (2000) rhizobial bacteria release lipochitooligosaccharide NOD factors, which have a role in nodulation initiation. Initiation of nodule development is dependent on signaling pathway of cytokinins (Tirichine et al., 2007; Reid et al., 2016). Many reports have shown that hormones like auxins, gibberellins, abscisic acid, ethylene, brassinosteroids etc. are involved in nodule development (Ferguson et al., 2005). Nodulation is regulated negatively by ethylene through the inhibition of Ca spiking due to Nod factor (Oldroyd and Downie, 2006; Ding et al., 2008). However, it is still unclear how nodule organogenesis and senescence are regulated by hormones. Nodulation inhibition by JA has recently been reported in Medicago truncatula (Sun et al., 2006) and Lotus japonicus (Nakagawa and Kawaguchi, 2006). EST analysis of Lotus japonica showed that during Rhizobium-Lotus interaction, genes involved in pathogen defense response and JA biosynthetic enzyme (AOC and OPRs) were upregulated and suppressed during the late nodule formation step (Shigeyama et al., 2012; Bordenave et al., 2013). According to Kouchi et al. (2004), in the JA biosynthetic pathway, genes responsible for lipooxygenase were mostly downregulated.

Senescence is one of the first physiological responses that were demonstrated by Ueda and Kato (1980) in Avena sativa (Figure 2). After that many authors have reported that JAs induce senescence (Schommer et al., 2008; Reinbothe et al., 2009). He et al. (2002) observed that an increase in JA levels activates the enzymes of JA biosynthetic pathway, which in turn activates the SENESCENCE ASSOCIATED GENES (SAGs). JA up-regulates the senescence related genes, which are: $S A G 12$, SAG14, SAG15, SEN1, SEN4, SEN5 (He et al., 2002). Expression of AOS and OPR3 in JA biosynthetic pathway and increase in JA are the indications of senescence due to JAs (van der Graaff et al., 2006). Seltmann et al. (2010) demonstrated that plants exhibit different phenotypes during senescence either induced or natural. However, they share symptoms like yellowing, etc.

In addition to organ senescence, JA plays an effective role in cell death as well as it reduces cell proliferation in human cancerous cells. However, no JAs have been reported from animals till date. Recently, it was reported that JAs also play a role in physiological response of secretion of floral nectar (Figure 2). Radhika et al. (2010a) demonstrated that floral nectar secretion is controlled by JAs in Brassica species. Interestingly, a significant production of floral nectar was observed in the flowers of $B$. napus, when JA is exogenously sprayed to them. However, nectar secretion decreased with decrease in JA application. JA also regulates nectar secretion in flowers as it causes secretion of defensive extra floral nectar (Bender et al., 2012; Heil, 2015). Yamane et al. (1982) demonstrated the occurrence of MeJA and JA in pollens and/or anthers of Camellia spp. On the background of Arabidopsis mutants it has been proposed that JAs are important for pollen development, stamen elongation and the pollen release timing (Liechti and Farmer, 2006). The dehiscence of anthers is delayed in the delayed dehiscence 1 (dde1) mutant of Arabidopsis resulting in inefficient fertilization. JA treatment has been found to restore the WT phenotype and helps the plant to produce seeds. During flower maturation, DDE1 accumulated in pistil, petals, and anther filamental tissues, but not in stomium. These results lead to the conclusion that JAsignaling regulates anther dehiscence. Studies on A. thaliana suggest that JA is capable of inducing and coordinating anther filament elongation, stomium opening at anthesis, and for viable pollen production (Stintzi and Browse, 2000). Mandaokar et al. (2006) have demonstrated that 13 transcription factors (TFs) such as MYB21 and MYB24, are involved in stamen maturation. These TFs are induced by JA, and they stimulated stamen development (Avanci et al., 2010). However, it is not yet explicit how endogenous levels of different components are altered due to its application. This certainly needs to be researched.

\section{JASMONATE SIGNALING PATHWAY}

Jasmonates are synthesized from lipid constituents and perceived by protein receptors that activate signal transduction pathway (Wasternack and Hause, 2013). This pathway brings modulations in plant responses regulated by JAs from transcription to translation (Wasternack and Hause, 2002; Santino et al., 2013; Wasternack and Hause, 2013). JAs are responsible for the inhibition of root length and thus have been used for exploring JA signaling mutants. The pioneer JA deficient mutant observed in Arabidopsis was Coronatine-insensitive1 (Coil; Kazan and Manners, 2008). Reduced sensitivity in root elongation has been shown by Coil mutants when treated with JA and coronatine (COR). COR, a phytotoxin secreted by P. syringae (a bacterial pathogen) is structurally and functionally similar to JA. The Coil mutants are defective in various functions that are JA dependent, e.g., pest resistance, pathogen resistance, wound response, secondary metabolite biosynthesis and fertility. The Coil gene codes for a protein having 16 leucine-rich repeats and F-box motif (Browse, 2009; Avanci et al., 2010). F-box protein forms multiprotein structures that serve as receptors (Avanci et al., 2010). According to Xie et al. (1998) Coil participated in removing repressors of the JA transduction. These repressors are mediated by SCF complexes found in all eukaryotes (Jiang et al., 2013; Wasternack and Hause, 2013). The composition of SCF complex is of proteineous type and is made up of SKP1, F-box and Cullin proteins. The SCF complex controls 
cell cycle regulation by activating ubiquitination of the cell cycle proteins and their degradation by the $26 \mathrm{~S}$ proteasome (Kazan and Manners, 2008).

Analysis of the Arabidopsis jar1 and jail mutants revealed that JAI (JASMONATE INSENSITIVE1) and JAR1 (JASMONATE RESISTANT1) have been reported to suppress effectiveness of externally applied JAs. Jar1 mutants are highly sensitive to pathogens (Rosahl and Feussner, 2005). JAR1 encodes a JA amino acid synthetase, and facilitates JA link to isoleucine thereby showing its role as a signaling molecule by suppressing root growth (Staswick, 2008; Wasternack and Kombrink, 2010). Staswick and Tiryaki (2004) demonstrated that AMP is replaced with an amino acid in JAR1. JAR4 a homolog of JAR1 have been recently cloned from Nicotiana attenuata (Kang et al., 2006). JAR4 deficient plants are more sensitive to insect Manduca sexta, demonstrating the importance of JA-Ile in plant defense (Wasternack, 2007).

JASMONATE INSENSITIVE1 (Jai1) is a sterile mutant of tomato and is resistant to JA (Li et al., 2004). Jail is a tomato coil homolog as Jai showed $68 \%$ amino acid identity with coil (Li et al., 2004). Jail mutant plants showed loss of seed maturation control, glandular trichomes appearance on leaves, unripened fruits and sepals indicating JA-signaling pathway in glandular trichomes of tomato defense responses ( $\mathrm{Li}$ et al., 2004).

Despite all these reports, a possible target for the Skp1/Cullin/F-boxCOI1 (SCF ${ }^{\text {Coil }) ~ c o m p l e x, ~ t h e r e ~ i s ~ n o ~ a n y ~}$ information available regarding the repressor that can provide evidences about the relationship between entire transcriptome and the SCF ${ }^{\text {Coil }}$ complex regulated by JA (Browse, 2009). The identification of the SCFCoil complex target molecule in the JASs signaling transduction. Thines et al. (2007) found upregulation of 31 genes over control, after treatment of Arabidopsis opr3 mutant with JA. Out of 31 genes, seven possess a 28-amino acid conserved domain (ZIM domain), eight code for the proteins with unknown function so these genes were named JASMONATE ZIM DOMAIN (jaz). The transgenic plants raised from JAZ1-GUS and JAZ6-GUS and the control plant containing GUS gene only showed intense blue color. Treatment of transgenic and control plants with $100 \mu \mathrm{M}$ JA for $1 \mathrm{~h}$ showed complete loss of GUS activity in transgenic plants with JAZ6-GUS and JAZ1-GUS, however, no loss in color was noticed in non-transgenic plants. Hence, it was suggested that Coil and JAZ proteins interaction is facilitated by JAs and consequently they help JAZ proteins to cause degradation by ubiquitination and proteasome 26S (Koo et al., 2011; Figure 3).

A protein JASMONATE INSENSITIVE3 (JAI3) has been identified by Chini et al. (2007) and it is included in JAZ protein family, which is recognized as a primary repressor of gene expression in the JAs signaling. JAI3 and other JAZ proteins have been reported to interact with Coil. The JA treatment degrades proteasome 26S due to the activity of Coil (Chung et al., 2010). Robson et al. (2010) demonstrated that JA signaling against shade and wounding are interlinked with JAZ1 stability in Arabidopsis. So, it can be recommended that JAI3/JAZ3 and JAZ1 are repressors of the JA signaling. In addition, $\mathrm{SCF}^{\mathrm{Coi} 1}$-dependent

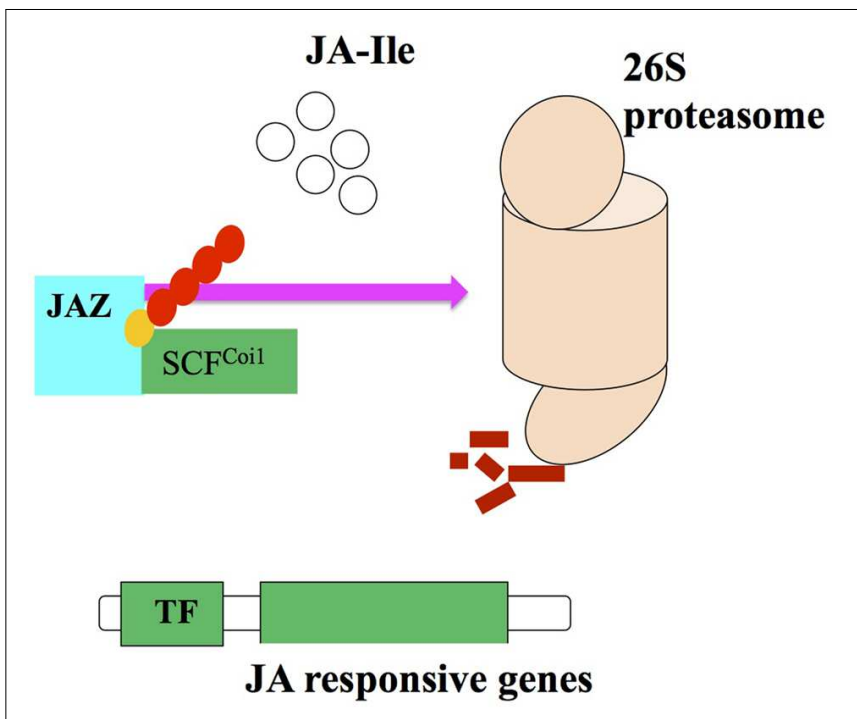

FIGURE 3 | Proteasome degredation via interaction of JA2 proteins with SCFCoi1 ubiquitin ligase upon JA-lle perception and activating the JA responses (adopted from Ballare, 2011 with modifications).

ubiquitination is required for the activation of JA responsive genes (Chini et al., 2007; Kazan and Manners, 2008).

Generally, plant adaptation to stresses is interlinked with stimulation of cascades of molecular processes including stress perception followed by transduction of a signal, and the expression of specific genes. As a result, plant stress tolerance capacity of transgenes is improved due to regulation of the function as well as structure of cellular components (Ashraf and Akram, 2009; Tuteja et al., 2012). For example, a wound-inducible transcript JASMONATE-ASSOCIATED1 (JAS1) regulated by the JA pathway was introduced into A. thaliana plants by Yan et al. (2007). They observed that the roots of transgenic Arabidopsis plants were better in growth than those of wild plants. Moreover, they confirmed this by using RNA interference by suppressing the action of JAS1 and found growth inhibition (Yan et al., 2007). In another study, effectiveness of MeJA in tuber formation in potatoes was assessed by introgression of Arabidopsis JMT (JA carboxyl methyltransferase) in potato plants. A significant improvement in number, size and weight was observed in transgenic potato plants due to overexpression of JMT mRNA levels (Sohn et al., 2011). Both JA and MeJA have shown a prominent role in the regulation of plant defense genes against different stresses. AOS converts hydroperoxide (lipoxygenase-derived fatty acid) to allene epoxide (a precursor of JA synthesis) in potato plants that led to an increase in the endogenous level of JA. Transgenic potato plants containing flax AOS cDNA had 6-12-fold increase in JA as compared to control plants. Similarly, the transgenic plants showed high expression of either drought stress- or wound-inducible genes (Harms et al., 1995). In addition, introgression of JMT obtained from Arabidopsis introduced into Escherichia coli catalyzed the formation of MeJA from JA. JMT RNA was identified in flowers, leaves, 
and rosettes of seedling plants, which indicated that JMT could respond to systemic or local signals produced in response to environmental stimuli. The transgenic plants were more resistant to Botrytis cinerea, a virulent fungus (Seo et al., 2001).

All these studies along with those mentioned in Table 2 clearly indicate that a number of components/genes of JA/MeJA including its receptors have been identified, but still more need to be explored. Up till now, a variety of roles of JAs have been observed in stress tolerance (biotic/abiotic), but the complete genetic cascade of JAs involved therein is partially determined which could be explored by comparing plants enriched/deficient in JAs after subjecting them to stress or nonstress conditions.

\section{CROSSTALK BETWEEN JASMONATES AND OTHER DEFENSE SIGNALING PATHWAY THROUGH MAPK CASCADES}

Mitogen activated protein (MAP) kinases are serine/threonine protein kinases that are involved in different intra- and extracellular signals. These MAP Kinases form a cascade where MAPK is phosphorylated and activated by MAPK kinase (MAPKK) followed by MAPKK kinase (MAPKKK; Ahmad et al., 2008). The involvement of MAPKs in JA or wound signaling in different plants has been reported (Meldau et al., 2012).

Seo et al. (1995) identified a wound-induced protein kinase (WIPK) in tobacco. The WIPK along with SIPK (SAinduced protein kinase) are responsible for modulating antiherbivore secondary metabolites and other herbivory-induced phytohormones (Heinrich et al., 2011). Expression of WIPK is genetically suppressed in transgenic tobacco plants and due to this they do not show synthesis of JA on injury. According to Farmer and Ryan (1992) early wound signal enhances the phosphorylation of protein kinases and subsequently stimulates the activity of enzymes involved in JAs biosynthesis. However, JA-insensitive A. thaliana dwarf mutant, mpk4 (MAPkinase4) has been observed to accumulate SA and show high expression of pathogenesis related protein (PR1) along with high resistance to P. syringae (Petersen et al., 2000). Plant reduction of dwarfing and no expression of PR1 have been observed in mpk4 plants having nahG gene encoding SA hydrolase, that decreased SA level (Turner et al., 2002). The expression of defense related genes, $S A R$ and $P R 1$, indicated that MPK4 acts as a mediator in the crosstalk between JA and SA pathways (Leon-Reyes et al., 2010).

In Arabidopsis, a JA-activated MAPK cascade, MAPK kinase3MAPK6, has been identified by Takahashi et al. (2007). Menke et al. (2004) earlier showed in Arabidopsis that MPK6 is a

TABLE 2 | Transgenic plants over-expressing genes involved in biosynthesis and/or signaling of jasmonates.

\begin{tabular}{|c|c|c|c|c|}
\hline Transgenic plants & Donor & Gene/transcript & Regulation in different plant attributes & Reference \\
\hline $\begin{array}{l}\text { Potato (Solanum } \\
\text { tuberosum L.) }\end{array}$ & $\begin{array}{l}\text { Flax (Linum } \\
\text { usitatissimum) }\end{array}$ & Allene oxide synthase (AOS) & $\begin{array}{l}\text { Transgenic plants had 6-12-fold higher level of JA than the wild } \\
\text { plants mechanical wounding. However, transgenic plants with } \\
\text { increased level of JA did not show changes in water state or in } \\
\text { the expression of water stress-responsive genes }\end{array}$ & Harms et al., 1995 \\
\hline Arabidopsis thaliana & A. thaliana & $\begin{array}{l}\text { JASMONATE-ASSOCIATED1 } \\
\text { (JAS1) }\end{array}$ & $\begin{array}{l}\text { The roots of transgenic plants overexpressing a gene of } \\
\text { unknown function were longer than those of wild-type plants }\end{array}$ & Yan et al., 2007 \\
\hline $\begin{array}{l}\text { Soybean [Glycine max } \\
\text { (L.) Merrill.] }\end{array}$ & $\begin{array}{l}\text { Brassica } \\
\text { campestris }\end{array}$ & NTR1 & $\begin{array}{l}\text { Transformed plants showed } 2-2.5 \text {-fold higher level of MeJA, } \\
\text { better plant height, lateral root development, but less primary } \\
\text { root elongation as compared to the wild-type plants }\end{array}$ & $\begin{array}{l}\text { Xue and Zhang, } \\
2007\end{array}$ \\
\hline Arabidopsis thaliana & Escherichia coli & $\begin{array}{l}\text { Jasmonic acid carboxyl } \\
\text { methyltransferase (JMT) }\end{array}$ & $\begin{array}{l}\text { Transgenic plants showed 3-fold increase inendogenous } \\
\text { MeJAlevel but no change in JA was observed. In addition, more } \\
\text { resistance against the virulent fungus Botrytis cinerea was } \\
\text { observed in transgenic plants }\end{array}$ & Seo et al., 2001 \\
\hline Panax ginseng & A. thaliana & $\begin{array}{l}\text { Arabidopsis jasmonic acid } \\
\text { carboxyl methyltransferase } \\
\text { (AtJMT) }\end{array}$ & $\begin{array}{l}\text { Transgenic plants showed high expression of PgSS1,PgSE1, } \\
\text { and PgDDS involved in ginsenoside biosynthetic pathways as } \\
\text { well as a MeJA-responsive gene, PgPR10-2 }\end{array}$ & Kim et al., 2012 \\
\hline Rice (Oryza sativa L.) & A. thaliana & AtJMT & $\begin{array}{l}\text { Seven different genes were regulated in both Ubi1:AtJMT and } \\
\text { drought-treated wild plant. Two genes, OsSDR and OsJMT1 } \\
\text { were involved in MeJA and ABA biosynthesis, respectively }\end{array}$ & Kim et al., 2009 \\
\hline Potato (S. tuberosum L.) & A. thaliana & $J M T$ & $\begin{array}{l}\text { Increased tuber yield and size in transgenic potato plants. In } \\
\text { addition an increase in JA, MeJA and tuberonic acid (TA) levels } \\
\text { and expression of allene oxide cyclase (AOC) and proteinase } \\
\text { inhibitor II (PINII) genes were also observed in transgenic plants } \\
\text { as compared to the control plants }\end{array}$ & Sohn et al., 2011 \\
\hline $\begin{array}{l}\text { Tobacco } \\
\text { (Nicotianatobacum L.) }\end{array}$ & $\ldots \ldots$ & $\begin{array}{l}\text { By silencing } \\
\text { monogalactosyldiacylglycerol } \\
(M G D G)\end{array}$ & $\begin{array}{l}\text { In response to wounding, the transgenic plants produced lower } \\
\text { levels of JA than wild-type plants. In addition, lipoxygenase } \\
(L O X 1), A O C \text {, hydroperoxidelyase }(H P L) \text { and proteinase inhibitor } \\
(P I-I \text { and } P I-I I) \text { were strongly diminished in transgenic plants } \\
\text { while they were highly activated in wild-type plants on } \\
\text { mechanical wounding }\end{array}$ & JunBin, 2009 \\
\hline
\end{tabular}


component of disease resistance. JA downregulates the TF MYC2, which was previously found to suppress JA/ET-related genes (Lorenzo et al., 2004). Takahashi et al. (2007) demonstrated that MKK3 also regulates this cascade. According to Takahashi et al. (2007) MKK3-MPK6 cascades involved in regulation of gene expression are dependant on JA/ET. However, MPK6 controls signals like cold, pathogens, salt, and JA is presented in a model in which MPK6 functions in three different pathways (Balbi and Devoto, 2008). The MKK4/MKK5-MPK6 and MKK2-MPK6 cascades were thoroughly studied by Lorenzo et al. (2004) and they found that they significantly regulated salt and chilling stress responses and ethylene induced plant defense (PDF1.2). The MKK3-MPK6 pathway retarded JA-induced root growth as well as gene expression of Vegetative Storage Protein2 (VSP2) via MYC2, a TF which regulates ethylene pathway by suppressing PDF1.2

Various MAP kinases are activated in Arabidopsis during wounding like MPK4, MPK6 and MPK1/MPK2 (OrtizMasia et al., 2007). In the absence of wound, MPK1/MPK2 gets activated by JA. Ortiz-Masia et al. (2007) found that wound and JA induction of MPK1/2 is Coil-dependent. In addition, $\mathrm{H}_{2} \mathrm{O}_{2}$ and $\mathrm{ABA}$ also activate $\mathrm{MPK} 1 / 2$, suggesting their role under stress conditions. Zhang et al. (2011) demonstrated that the group C (GhMPK2) MAPK gene isolated from cotton has a role in signaling pathway and defends the plants from pathogens and oxidative stress. Over-expression of GhMPK2 in transgenic tobacco showed a significant resistance to viral and fungal attack due to over-expression of pathogenesis-related (PR) genes, such as PR1, PR2, PR4, and PR5 in transgenic plants (2011). García-Andrade et al. (2011) also demonstrated the role of defense-related gene (OP3) in Arabidopsis. Here double mutants showed callose deposition regulation by JA and ABA in response to necrotrophic fungal pathogens like $B$. cinerea and Plectosphaerella cucumerina.

Camp et al. (2000) demonstrated that MAK phosphatases (MKP) are repressors of MAPKs. MKPs have been observed to play a role in abiotic stresses and hormonal regulation in Arabidopsis and tobacco (Naoi and Hashimoto, 2004). Reports about the significance of MKPs in monocots are sparse. Wounding induces OSMKP1 expression in rice and it has been shown that OSMKP1 acts as a suppressor of wound responses (Balbi and Devoto, 2008).

Schweighofer et al. (2007) identified a novel stress signal regulator in Arabidopsis, i.e., AP2C1 which is a MAPK Ser/Thr phosphatase. Overexpression of $\mathrm{AP} 2 \mathrm{C} 1$ makes the plants to lose their resistance potential to Botrytis and also causes suppression in ethylene biosynthesis (Balbi and Devoto, 2008). G-proteins are also reported to be linked with MeJA signaling (Trusov et al., 2006; Okamoto et al., 2009). Recently, it was shown that treatments of Pisum sativum seedlings with MeJA upregulated MPK3 and G-beta subunit of G-proteins genes which later resulted in their interaction (Bhardwaj et al., 2011). Recently, Meldau et al. (2012) observed that irWIPK and LOX3 deficient $N$. attenuata plants performed better as compared to WT ones. Similarly, irSIPK mutant plants, showed suppression in JA signaling and performed not well as did the WT plants. So it can be suggested that signaling mediated by WIPK and SIPK is not involved in growth promotion of $N$. attenuata plants. Both MAPKs played a differential role in regulating the plants' growth-defense balance (Meldau et al., 2012). In addition, Arabidopsis MAP kinase (mpk6), jar1 and coil mutants plants were altered in JA signaling as well as they were not protected from fungal attack even on $\mathrm{N}$-isobutyl decanamide exogenous application which is opposite to those of SA eds16/sid2-1 mutants (Mendez-Bravo et al., 2011).

It has been found that MAPK kinases are important components of JA signaling and biosynthesis pathways, but NO, ROS, $\mathrm{Ca}, \mathrm{ABA}$, ethylene, and SA are also important regulators of plant fitness during JA signal transduction and synthesis. The exploration of other signaling molecules can be beneficial to examine the details of underlying molecular mechanisms of JA signal transduction.

\section{CONCLUSION AND FUTURE PERSPECTIVES}

It is now clear that JAs are involved in a diversity of functions. Much progress has been made in identification and characterization of several enzymes involved in biosynthesis and metabolism of JA and its derivatives. Among the new chemicals identified, 'arabidopsides', esterfied oxylipin derivatives, are of great importance. They play a crucial role in plant defense. Recent findings on the role of JA in reproduction, flower nectar secretion, G-protein signaling, and cancerous diseases have opened new vistas for future research.

In view of the above-mentioned studies it is clear that JAs play an essential role from seed germination to senescence, but there is limited information available in the literature on how these plant processes vary from species to species with JA application.

A diverse range of components/genes of JA/MeJA including its receptors have been identified (Table 2), but their appropriate functions still need to be explored. In addition, the complete genetic cascade of JAs involved in genetically engineered transgenic plants is partially determined which could be explored by comparing plants enriched/deficient in JAs after subjecting them to stress or non-stress conditions.

Much work is to be done in near future to find out the proper answers of the questions like action of JA metabolites, and identification of universal JA receptors etc. Complete signaling pathways involving MAPKs, CDPK, TGA, SIPK, WIPK, and WRKY TFs are yet to be studied to understand the complete mechanism of action of JA.

The most important aspect is that the extent of effectiveness of JAs like other hormones is plant species dependent. They affect the growth of different plants to a different extent. JAs play a role from germination up to senescence. However, various genes involved in growth regulation at different stages of development, are yet to be identified. How far and up to what extent these genes are involved in cross-talks also needs to be explored. 


\section{AUTHOR CONTRIBUTIONS}

PA, SR, and AG wrote the manuscript. SAS, NAA, MA, and SG contributed in section 2 and 3 of this manuscript. They also reviewed and updated the manuscript.

\section{REFERENCES}

Adams, E., and Turner, J. (2010). COI1, a jasmonate receptor, is involved in ethylene-induced inhibition of Arabidopsis root growth in the light. J. Exp. Bot. 61, 4373-4386. doi: 10.1093/jxb/erq240

Ahmad, P., Ashraf, M., Younis, M., Hu, X., Kumar, A., Akram, N. A., et al. (2011a). Role of transgenic plants in agriculture and biopharming. Biotechnol. Adv. 30, 524-540. doi: 10.1016/j.biotechadv.2011.09.006

Ahmad, P., Jeleel, C. A., and Azooz, M. M. (2011b). "Free radical production, oxidative damage and antioxidant defense mechanisms in plants under abiotic stress," in Oxidative Stress: Role of Antioxidats in Plants, eds P. Ahmad and S. Umar (New Delhi: Studium Press Pvt. Ltd), 19-53.

Ahmad, P., Jaleel, C. A., Salem, M. A., Nabi, G., and Sharma, S. (2010). Roles of enzymatic and non-enzymatic antioxidants in plants during abiotic stress. Crit. Rev. Biotechnol. 30, 161-175. doi: 10.3109/07388550903524243

Ahmad, P., Nabi, G., and Ashraf, M. (2011c). Cadmium-induced oxidative damage in mustard [Brassica juncea (L.) Czern. \& Coss.] plants can be alleviated by salicylic acid. S. Afr. J. Bot. 77, 36-44. doi: 10.1016/j.sajb.2010.05.003

Ahmad, P., Sarwat, M., and Sharma, S. (2008). Reactive oxygen species, antioxidants and signaling in plants. J. Plant Biol. 51, 167-173. doi: 10.1007/BF03030694

Akram, N. A., and Ashraf, M. (2013). Regulation in plant stress tolerance by a potential plant growth regulator, 5-aminolevolinic acid (ALA). J. Plant Growth Regul. 32, 663-679. doi: 10.1007/s00344-013-9325-9

Akram, N. A., Ashraf, M., and Al-Qurainy, F. (2012). Aminolevulinic acid-induced changes in some key physiological attributes and activities of antioxidant enzymes in sunflower (Helianthus annuus L.) plants under saline regimes. Sci. Hortic. 142, 143-148. doi: 10.1016/j.scienta.2012.05.007

Anjum, S., Xie, X. Y., Wang, L. C., Saleem, M. F., Man, C., and Wang, L. (2011). Morphological, physiological and biochemical responses of plants to drought stress. Afr. J. Agric. Res. 6, 2026-2032.

Ashraf, M., and Akram, N. A. (2009). Improving salinity tolerance of plants through conventional breeding and genetic engineering: an analytical comparison. Biotechnol. Adv. 27, 744-752. doi: 10.1016/j.biotechadv.2009.05.026

Ashraf, M., Akram, N. A., Arteca, R. N., and Foolad, M. R. (2010). The physiological, biochemical and molecular roles of brassinosteroids and salicylic acid in plant processes and salt tolerance. Crit. Rev. Plant Sci. 29, 162-190. doi: 10.1080/07352689.2010.483580

Avanci, N. C., Luche, D. D., Goldman, G. H., and Goldman, M. H. S. (2010). Jasmonates are phytohormones with multiple functions, including plant defense and reproduction. Genet. Mol. Res. 9, 484-505. doi: 10.4238/vol9$\operatorname{lgmr} 754$

Ayala-Zavala, J. F., Oms-Oliu, G., Odriozola-Serrano, I., González-Aguilar, G. A., Alvarez-Parrilla, E., and Martín-Belloso, O. (2008). Bio-preservation of freshcut tomatoes using natural antimicrobials. Eur. Food Res. Technol. 226, 10471055. doi: 10.1007/s00217-007-0630-Z

Baenas, N., García-Viguera, C., and Moreno, D. A. (2014). Elicitation: a tool for enriching the bioactive composition of foods. Molecules 19, 13541-13563. doi: 10.3390/molecules190913541

Balbi, V., and Devoto, Z. (2008). Jasmonate signalling network in Arabidopsis thaliana: crucial regulatory nodes and new physiological scenarios. New Phytol. 177, 301-318. doi: 10.1111/j.1469-8137.2007.02292.x

Baldwin, I. T. (2010). Plant volatiles. Curr. Biol. 20, 392-397. doi: 10.1016/j.cub.2010.02.052

Ballare, C. L. (2011). Jasmonate-induced defenses: a tale of intelligence, collaborators and rascals. Trends Plant Sci. 16:5. doi: 10.1016/j.tplants.2010.12.001

Bandurska, H., and Stroiński, A. (2003). The effect of jasmonic acid on the accumulation of ABA, proline and spermidine and its influence on membrane

\section{ACKNOWLEDGMENT}

The authors extend their appreciation to the Deanship of Scientific Research, College of Sciences Research Center, King Saud University, Riyadh, Saudi Arabia for supporting the project.

injury under water deficit in two barley genotypes. Acta Physiol. Plant. 25, 279-285. doi: 10.1007/s11738-003-0009-0

Bari, R., and Jones, J. D. G. (2009). Role of plant hormones in plant defence responses. Plant Mol. Biol. 69, 473-488. doi: 10.1007/s11103-008-9435-0

Bell, E., Creelman, R. A., and Mullet, J. E. (1995). A chloroplast lipoxygenase is required for wound-induced jasmonic acid accumulation in Arabidopsis. Proc. Natl. Acad. Sci. U.S.A. 92, 8675-8679. doi: 10.1073/pnas.92. 19.8675

Bender, R., Klinkenberg, P., Jiang, Z., Bauer, B., Karypis, G., Nguyen, N., et al. (2012). Functional genomics of nectar production in the Brassicaceae. Flora 207, 491-496. doi: 10.1007/s00497-009-0112-5

Benedetti, C. E., Xie, D., and Turner, J. G. (1995). COI1-dependent expression of an Arabidopsis vegetative storage protein in flowers and siliques and in response to methyl jasmonate. Plant Physiol. 109, 567-572. doi: 10.1104/pp.109.2.567

Bhardwaj, D., Sheikh, A. H., Sinha, A. K., and Tuteja, N. (2011). Stress induced $\beta$ subunit of heterotrimeric G-proteins from Pisum sativum interacts with mitogen activated protein kinase. Plant Signal. Behav. 6, 287-292. doi: 10.4161/psb.6.2.14971

Bordenave, C. D., Escaray, F. J., Menendez, A. B., Serna, E., Carrasco, P., Ruiz, O. A., et al. (2013). Defense responses in two ecotypes of Lotus japonicus against non-pathogenic Pseudomonas syringae. PLoS ONE 8:e83199. doi: 10.1371/journal.pone.0083199

Boter, M., Ruiz-Rivero, O., Abdeen, A., and Prat, S. (2004). Conserved MYC transcription factors play a key role in jasmonate signaling both in tomato and Arabidopsis. Genes Dev. 18, 1577-1591. doi: 10.1101/gad.297704

Browse, J. (2009). Jasmonate: preventing the maize tassel from getting in touch with his feminine side. Sci. Signal. 2:e9. doi: 10.1126/scisignal.259pe9

Browse, J., and Howe, G. A. (2008). New weapons and a rapid response against insect attack. Plant Physiol. 146, 832-838. doi: 10.1104/pp.107. 115683

Bussell, J. D., Behrens, C., Ecke, W., and Eubel, H. (2013). Arabidopsis peroxisome proteomics. Front. Plant Sci. 4:101. doi: 10.3389/fpls.2013. 00101

Camp, M., Nichols, A., and Arkinstall, S. (2000). Dual specificity phosphatases: a gene family for control of MAP kinase functions. FASEB J. 14, 6-16.

Chanjirakul, K., Wang, S. Y., Wang, C. Y., and Siriphanich, J. (2006). Effect of natural volatile compounds on antioxidant capacity and antioxidant enzymes in raspberries. Postharvest Biol. Technol. 40, 106-115. doi: 10.1016/j.postharvbio.2006.01.004

Chen, J., Zou, X., Liu, Q., Wang, F., Feng, W., and Wan, N. (2014). Combination effect of chitosan and methyl jasmonate on controlling Alternaria alternata and enhancing activity of cherry tomato fruit defense mechanisms. Crop Prot. 56, 31-36. doi: 10.1016/j.cropro.2013.10.007

Chini, A., Fonseca, S., Fernández, G., Adie, B., Chico, J. M., Lorenzo, O., et al. (2007). The JAZ family of repressors is the missing link in jasmonate signalling. Nature 448, 666-671. doi: 10.1038/nature06006

Chung, H. S., Cooke, T. F., DePew, C. L., Patel, L. C., Ogawa, N., Kobayashi, Y., et al. (2010). Alternative splicing expands the repertoire of dominant JAZ repressors of jasmonate signaling. Plant J. 63, 613-622. doi: 10.1111/j.1365313X.2010.04265.x

Chung, H. S., Koo, A. J., Gao, X., Jayanty, S., Thines, B., Jones, A. D., et al. (2008). Regulation and function of Arabidopsis JASMONATE ZIM-domain genes in response to wounding and herbivory. Plant Physiol. 1468, 952-964. doi: 10.1104/pp.107.115691

Cipollini, D. (2010). Constitutive expression of methyl jasmonates inducible responses delays reproduction and constrains fitness responses to nutrients in Arabidopsis thaliana. Evol. Ecol. 24, 59-68. doi: 10.1007/s10682-008-9290-0

Creelman, R. A., and Mullet, J. E. (1995). Jasmonic acid distribution and action in plants: regulation during development and response to biotic and abiotic stress. Proc. Natl. Acad. Sci. U.S.A. 92, 4114-4119. doi: 10.1073/pnas.92.10.4114 
Creelman, R. A., and Mullet, J. E. (1997). Biosynthesis and action of jasmonates in plants. Annu. Rev. Plant Physiol. Plant Mol. Biol. 48, 355-381. doi: 10.1146/annurev.arplant.48.1.355

Dave, A., Hernández, M. L., He, Z., Andriotis, V. M. E., Vaistij, F. E., Larson, T. R., et al. (2011). 12-Oxo-phytodienoic acid accumulation during seed development represses seed germination in Arabidopsis. Plant Cell 23, 583-599. doi: $10.1105 /$ tpc.110.081489

De Geyter, N., Gholami, A., Goormachtig, S., and Goossens, A. (2012). Transcriptional machineries in jasmonate-elicited plant secondary metabolism. Trends Plant Sci. 17, 349-359. doi: 10.1016/j.tplants.2012.03.001

De Rosa, V. E. Jr., Nogueira, F. T. S., Menossi, M., Ulian, E. C., and Arruda, P. (2005). Identification of methyl jasmonate-responsive genes in sugarcane using cDNA arrays. Braz. J. Plant Physiol. 17, 173-180. doi: 10.1590/S167704202005000100014

del Amor, F. M., and Cuadra-Crespo, P. (2011). Alleviation of salinity stress in broccoli using foliar urea or methyl-jasmonate: analysis of growth, gas exchange, and isotope composition. Plant Growth Regul. 63, 55-62. doi: 10.1007/s10725-010-9511-8

Delker, C., Stenzel, I., Hause, B., Miersch, O., Feussner, I., and Wasternack, C. (2006). Jasmonate biosynthesis in Arabidopsis thaliana - enzymes, products, regulation. Plant Biol. 8, 297-306. doi: 10.1055/s-2006-923935

Denancé, N., Sánchez-Vallet, A., Goffner, D., and Molina, A. (2013). Disease resistance or growth: the role of plant hormones in balancing immune responses and fitness costs. Front. Plant Sci. 4:155. doi: 10.3389/fpls.2013.00155

Ding, Y., Kalo, P., Yendrek, C., Sun, J., Liang, Y., Marsh, J. F., et al. (2008). Abscisic acid coordinates nod factor and cytokinin signaling during the regulation of nodulation in Medicago truncatula. Plant Cell 20, 2681-2695. doi: 10.1105/tpc.108.061739

Droby, S., Porat, R., Cohen, L., Weiss, B., Shapiro, B., Philosoph-Hasas, S., et al. (1999). Suppressing green mold decay in grapefruit with postharvest jasmonates application. J. Am. Soc. Hortic. Sci. 124, 184-188.

Enteshari, S. H., and Jafari, T. (2013). The effects of methyl jasmonate and salinity on germination and seedling growth in Ocimum basilicum L. stress. Iran J. Plant Physiol. 3, 749-756.

Erb, M., Meldau, S., and Howe, G. A. (2012). Role of phytohormones in insect-specific plant reactions. Trends Plant Sci. 17, 250-259. doi: 10.1016/j.tplants.2012.01.003

Faraz, K. (2006). The Effects of Arabidopsis thaliana Sulfotransferase 2a (AtST2a) Over-Expression on Tuber Formation. Masters thesis, Concordia University.

Farmer, E. E., and Ryan, C. A. (1992). Octadecanoid precursors of jasmonic acid activate the synthesis of wound-inducible proteinase inhibitors. Plant Cell 4, 129-134. doi: $10.2307 / 3869566$

Farrant, J. M., and Ruelland, E. (2015). Plant signaling mechanisms in response to environment. Environ. Exp. Bot. 114, 1-3. doi: 10.1016/j.envexpbot.2015.02.006

Faurie, B., Cluzet, S., and Merillon, J. M. (2009). Implication of signaling pathways involving calcium, phosphorylation and active oxygen species in methyl jasmonate-induced defense responses in grapevine cell cultures. J. Plant Physiol. 66, 1863-1877. doi: 10.1016/j.jplph.2009.05.015

Ferguson, B. J., Ross, J. J., and Reid, J. B. (2005). Nodulation phenotypes of gibberellin and brassinosteroid mutants of pea. Plant Physiol. 138, 2396-2405. doi: 10.1104/pp.105.062414

Fonseca, S., Chico, J. M., and Solano, R. (2009). The jasmonate pathway: the ligand, the receptor and the core signalling module. Curr. Opin. Plant Biol. 12, 539-547. doi: 10.1016/j.pbi.2009.07.013

Franceschi, V. R., Krekling, T., and Christiansen, E. (2002). Application of methyl jasmonate on Picea abies (pinaceae) stems induces defense-related responses in phloem and xylem. Am. J. Bot. 89, 578-586. doi: 10.3732/ajb.89.4.578

Franceschi, V. R., Wittenbach, V. A., and Giaquinta, R. T. (1983). Paraveinal mesophyll of soybean leaves in relation to assimilate transfer and compartmentation. Plant Physiol. 72, 586-589. doi: 10.1104/pp.72.2.586

Gao, Q. M., Venugopal, S., Navarre, D., and Kachroo, A. (2011). Low oleic acid derived repression of jasmonic acid-inducible defense responses requires the WRKY50 and WRKY51 proteins. Plant Physiol. 155, 464-476. doi: 10.1104/pp.110.166876

Gao, X. P., Wang, X. F., Lu, Y. F., Zhang, L. Y., Shen, Y. Y., Liang, Z., et al. (2004). Jasmonic acid is involved in the water-stressed-induced betaine accumulation in pear leaves. Plant Cell Environ. 27, 497-507. doi: 10.1111/j.1365-3040.2004.01167.x
García-Andrade, J., Ramírez, V., Flors, V., and Vera, P. (2011). Arabidopsis ocp3 mutant reveals a mechanism linking $\mathrm{ABA}$ and JA to pathogen-induced callose deposition. Plant J. 67, 783-794. doi: 10.1111/j.1365-313X.2011.04633.x

Gfeller, A., Dubugnon, L., Liechti, R., and Farmer, E. E. (2010a). Jasmonate biochemical pathway. Sci. Signal. 16:3.

Gfeller, A., Liechti, R., and Farmer, E. E. (2010b). Arabidopsis jasmonate signaling pathway. Sci. Signal. 3:4. doi: 10.1126/scisignal.3109cm4

Ghasemnezhad, M., and Javaherdashti, M. (2008). Effect of methyl jasmonate treatment on antioxidant capacity, internal quality and postharvest life of raspberry fruit. Caspian J. Environ. Sci. 6, 73-78.

Gidda, K. S., Miersch, O., Schmidt, J., Wasternack, C., and Varin, L. (2003). Biochemical and molecular characterization of a hydroxy-jasmonate sulfotransferase from Arabidopsis thaliana. J. Biol. Chem. 278, 17895-17900. doi: 10.1074/jbc.M211943200

Gonzalez-Aguilar, G. A., Buta, J. G., and Wang, C. Y. (2003). Methyl jasmonate and modified atmosphere packaging (MAP) reduce decay and maintain postharvest quality of papaya 'sunrise'. Postharvest Biol. Technol. 28, 361-370. doi: 10.1016/S0925-5214(02)00200-4

Gonzalez-Aguilar, G. A., Fortiz, J., Cruz, R., Báez, R., and Wang, C. Y. (2000). Methyl jasmonate reduces chilling injury and maintains postharvest quality of mango fruit. J. Agric. Food Chem. 48, 515-519. doi: 10.1021/jf9902806

Grantz, A. A., Brummell, D. A., and Bennett, A. B. (1995). Ascorbate free radical reductase mRNA levels are induced by wounding. Plant Physiol. 108, 411-418. doi: 10.1104/pp.108.1.411

Harms, K., Atzorn, R., Brash, A., Kuhn, H., Wasternack, C., Willmitzer, L., et al. (1995). Expression of a flax allene oxide synthase cDNA leads to increased endogenous jasmonic acid (JA) levels in transgenic potato plants but not to a corresponding activation of JA-responding genes. Plant Cell 7, 1645-1654. doi: $10.2307 / 3870026$

He, Y., Fukushige, H., Hildebrand, D. F., and Gan, S. (2002). Evidence supporting a role of jasmonic acid in Arabidopsis leaf senescence. Plant Physiol. 128, 876-884. doi: 10.1104/pp.010843

Heil, M. (2015). Extrafloral nectar at the plant-insect interface: a spotlight on chemical ecology, phenotypic plasticity, and food webs. Annu. Rev. Entomol. 60, 213-232. doi: 10.1146/annurev-ento-010814-020753

Heinrich, M., Baldwin, I. T., and Wu, J. (2011). Two mitogen-activated protein kinase kinases, MKK1 and MEK2, are involved in woundingand specialist lepidopteran herbivore Manduca sexta-induced responses in Nicotiana attenuate. J. Exp. Bot. 62, 4355-4365. doi: 10.1093/jxb/err162

Honda, I., Seto, H., Turuspekov, Y., Watanabe, Y., and Yoshida, S. (2006). Inhibitory effects of jasmonic acid and its analogues on barley (Hordeum vulgare L.) anther extrusion. Plant Growth Regul. 48, 201-206. doi: 10.1007/s10725-006-0003-9

Hossain, M. A., Munemasa, S., Uraji, M., Nakamura, Y., Mori, I. C., and Murata, Y. (2011). Involvement of endogenous abscisic acid in methyl jasmonate-induced stomatal closure in Arabidopsis. Plant Physiol. 156, 430-438. doi: $10.1104 /$ pp.111.172254

Howe, G., and Jander, G. (2008). Plant immunity to insect herbivores. Annu. Rev. Plant Biol. 59, 41-66. doi: 10.1146/annurev.arplant.59.032607.092825

Jalalpour, Z., Shabani, L., Afghani, L., Sharifi-Tehrani, M., and Amini, S. (2014). Stimulatory effect of methyl jasmonate and squalestatin on phenolic metabolism through induction of LOX activity in cell suspension culture of yew. Turk. J. Biol. 38, 76-82. doi: 10.3906/biy-1306-91

Javid, M. G., Sorooshzadeh, A., Moradi, F., Sanavy, S. A. M. M., and Allahdadi, I. (2011). The role of phytohormones in alleviating salt stress in crop plants. Aust. J. Crop Sci. 5, 726-734.

Jiang, W., Bikard, D., Cox, D., Zhang, F., and Marraffini, L. A. (2013). RNA guided editing of bacterial genomes using CRISPR-Cas systems. Nat. Biotechnol. 31, 233-239. doi: 10.1038/nbt.2508

JunBin, W. (2009). Monogalactosyl diacylglycerol deficiency affects jasmonic acid biosynthesis and defense responses to insect herbivores in Nicotiana tobaccum. Plant Sci. 176, 279-285. doi: 10.1016/j.plantsci.2008.11.003

Kang, J. H., Wang, L., Giri, A., and Baldwin, I. T. (2006). Silencing threonine deaminase and JAR4 in Nicotiana attenuata impairs jasmonic acid-isoleucinemediated defenses against Manduca sexta. Plant Cell 18, 3303-3320. doi: $10.1105 /$ tpc. 106.041103

Kazan, K., and Manners, J. M. (2008). Jasmonate signaling: toward an integrated view. Plant Physiol. 146, 1459-1468. doi: 10.1104/pp.107.115717 
Kazan, K., and Manners, J. M. (2011). The interplay between light and jasmonate signalling during defence and development. J. Exp. Bot. 62, 4087-4100. doi: 10.1093/jxb/err142

Kazemi, M. (2014). Effect of Foliar Application with salicylic acid and methyl jasmonate on growth, flowering, yield and fruit quality of tomato. Bull. Env. Pharmacol. Life Sci. 3, 154-158.

Kim, E. H., Kim, Y. S., Park, S. H., Koo, Y. J., Choi, Y. D., Chung, Y. Y., et al. (2009). Methyl jasmonate reduces grain yield by mediating stress signals to alter spikelet development in rice. Plant Physiol. 149, 1751-1760. doi: 10.1104/pp.108.134684

Kim, W. C., Ko, J. H., and Han, K. H. (2012). Identification of a cis-acting regulatory motif recognized by MYB46, a master transcriptional regulator of secondary wall biosynthesis. Plant Mol. Biol. 78, 489-501. doi: 10.1007/s11103012-9880-7

Kobayashi, T., Yamaguchi, T., Hamanaka, S., Kato-Itoh, M., Yamazaki, Y., Ibata, M., et al. (2010). Generation of rat pancreas in mouse by interspecific blastocyst injection of pluripotent stem cells. Cell 142, 787-799. doi: 10.1016/j.cell.2010.07.039

Koda, Y. (1997). Possible involvement of jasmonates in various morphogenic events. Physiol. Plant. 100, 639-646. doi: 10.1111/j.1399-3054.1997.tb03070.x

Kondo, S., Tomiyama, A., and Seto, H. (2000). Changes of endogenous jasmonic acid and methyl jasmonate in apples and sweet cherries during fruit development. J. Am. Soc. Hortic. Sci. 125, 282-287.

Koo, A. J. K., Cooke, T. F., and Howe, G. A. (2011). Cytochrome P450 CYP94B3 mediates catabolism and inactivation of the plant hormone jasmonoyl-L-isoleucine. Proc. Natl. Acad. Sci. U.S.A. 108, 9298-9303. doi: 10.1073/pnas.1103542108

Koo, A. J. K., Gao, X., Jones, A. D., and Howe, G. A. (2009). A rapid wound signal activates the systemic synthesis of bioactive jasmonates in Arabidopsis. Plant J. 59, 974-986. doi: 10.1111/j.1365-313X.2009.03924.x

Koo, A. J. K., and Howe, G. A. (2012). Catabolism and deactivation of the lipidhormone jasmonoy L-isoleucine. Front. Plant Sci. 3:19. doi: 10.3389/fpls.2012.00019

Kouchi, H., Shimomura, K., Hata, S., Hirota, A., Wu, G. J., Kumagai, H., et al. (2004). Large-scale analysis of gene expression profiles during early stages of root nodule formation in a model legume, Lotus japonicus. DNA Res. 11, 263-274. doi: 10.1093/dnares/11.4.263

Koyro, H. W., Ahmad, P., and Geissler, N. (2011). "Abiotic stress responses in plants: an overview," in Environmental Adaptations and Stress Tolerance of Plants in the Era of Climate Change, eds P. Ahmad and M. N. V. Prasad (New York, NY: Springer Science+Business Media), 1-28.

Krokene, P., Nagy, N. E., and Solheim, H. (2008). Methyl jasmonate and oxalic acid treatment of Norway spruce: anatomically based defense responses and increased resistance against fungal infection. Tree Physiol. 28, 29-35. doi: 10.1093/treephys/28.1.29

Ku, K. M., Jeffery, E. H., and Juvik, J. A. (2014). Optimization of methyl jasmonate application to broccoli florets to enhance health promoting phytochemical content. J. Sci. Food Agric. 94, 2090-2096. doi: 10.1002/jsfa.6529

Kumar, R., Khurana, A., and Sharma, A. K. (2014). Role of plant hormones and their interplay in development and ripening of fleshy fruits. J. Exp. Bot. 65, 4561-4575. doi: 10.1093/jxb/eru277

Kupper, F. C., Gaquerel, E., Cosse, A., Adas, F., Peters, A. F., Muller, D. G., et al. (2009). Free fatty acids and methyl jasmonate trigger defense reactions in Laminaria digitata. Plant Cell Physiol. 50, 789-800. doi: 10.1093/pcp/pcp023

Leon-Reyes, A., Van der Does, D., De Lange, E. S., Delker, C., Wasternack, C., Van Wees, S. C. M., et al. (2010). Salicylate-mediated suppression of jasmonateresponsive gene expression in Arabidopsis is targeted downstream of the jasmonate biosynthesis pathway. Planta 232, 1423-1432. doi: 10.1007/s00425010-1265-Z

Li, L., Zhao, Y., McCaig, B. C., Wingerd, B. A., Wang, J., Whalon, M. E., et al. (2004). The tomato homolog of Coronatine-insensitivel is required for the maternal control of seed maturation, jasmonate-signaled defense responses, and glandular trichome development. Plant Cell 16, 126-143. doi: $10.1105 /$ tpc. 017954

Liechti, R., and Farmer, E. (2006). Jasmonate biochemical pathway. Sci. STKE 322:3. Liu, F., Jiang, H., Ye, S., Chen, W. P., Liang, W., Xu, Y., et al. (2010). The Arabidopsis $\mathrm{P} 450$ protein CYP82C2 modulates jasmonate-induced root growth inhibition, defense gene expression and indole glucosinolate biosynthesis. Cell Res. 20, 539-552. doi: 10.1038/cr.2010.36
Liu, H., Li, X., Xiao, J., and Wang, S. (2012). A convenient method for simultaneous quantification of multiple phytohormones and metabolites: application in study of rice-bacterium interaction. Plant Methods 8:2. doi: 10.1186/17464811-8-2

Lorenzo, O., Chico, J. M., Sanchez-Serrano, J. J., and Solano, R. (2004). JASMONATE-INSENSITIVE1 encodes a MYC transcription factor essential to discriminate between different jasmonate-regulated defense responses in Arabidopsis. Plant Cell 16, 1938-1950. doi: 10.1105/tpc.022319

Ma, C., Wang, Z. Q., Zhang, L. T., Sun, M. M., and Lin, T. B. (2014). Photosynthetic responses of wheat (Triticum aestivum L.) to combined effects of drought and exogenous methyl jasmonate. Photosynthetica 52, 377-385. doi: 10.1007/s11099-014-0041-x

Maksymiec, W., and Krupa, Z. (2002). The in vivo and in vitro influence of methyl jasmonate on oxidative processes in Arabidopsis thaliana leaves. Acta Physiol. Plant 24, 351-357. doi: 10.1007/s11738-002-0029-1

Mandaokar, A., Thines, B., Shin, B., Lange, B. M., Choi, G., Koo, Y. J., et al. (2006). Transcriptional regulators of stamen development in Arabidopsis identified by transcriptional profiling. Plant J. 46, 984-1008. doi: 10.1111/j.1365313X.2006.02756.x

Marchive, C., Léon, C., Kappel, C., Coutos-Thévenot, P., Corio-Costet, M. F., Delrot, S., et al. (2013). Over-expression of VvWRKY1 in grapevines induces expression of jasmonic acid pathway-related genes and confers higher tolerance to the downy mildew. PLOS ONE 8:e54185. doi: 10.1371/journal.pone.00 54185

McConn, M., Creelman, R. A., Bell, E., Mullet, J. E., and Browse, J. (1997). Jasmonate is essential for insect defense in Arabidopsis. Proc. Natl. Acad. Sci. U.S.A. 94, 5473-5477. doi: 10.1073/pnas.94.10.5473

Mehrjerdi, Z. A., Abarashi, Z., Mansoori, S., Deylamizadeh, A., Fadardi, J. S., Noroozi, A., et al. (2013). Methamphetamine use among Iranian heroin kerackdependent women: implications for treatment. Int. J. High Risk Behav. Addict. 2, 15-21. doi: 10.5812/ijhrba.10216

Meldau, S., Erb, M., and Baldwin, I. T. (2012). Defence on demand: mechanisms behind optimal defence patterns. Ann. Bot. 110, 1503-1514. doi: $10.1093 / \mathrm{aob} / \mathrm{mcs} 212$

Mendez-Bravo, A., Calderon-Vazquez, C., Ibarra-Laclette, E., Raya-Gonzalez, J., Ramirez-Chavez, E., Molina-Torres, J., et al. (2011). Alkamides activate jasmonic acid biosynthesis and signaling pathways and confer resistance to Botrytis cinerea in Arabidopsis thaliana. PLoS ONE 6:e27251. doi: 10.1371/journal.pone.0027251

Menke, F. L., van Pelt, J. A., Pieterse, C. M., and Klessig, D. F. (2004). Silencing of the mitogen-activated protein kinase MPK6 compromises disease resistance in Arabidopsis. Plant Cell 16, 897-907. doi: 10.1105/tpc.015552

Moreno, J. E., Tao, Y., Chory, J., and Ballare, C. L. (2009). Ecological modulation of plant defense via phytochrome control of jasmonates sensitivity. Proc. Natl. Acad. Sci. U.S.A. 106, 4935-4940. doi: 10.1073/pnas.09007 01106

Nafie, E., Hathout, T., Al, S., and Al, M. (2011). Jasmonic acid elicits oxidative defense and detoxification systems in Cucumis melo L. cells. Braz. J. Plant Physiol. 23, 161-174. doi: 10.1590/S1677-04202011000200008

Nakagawa, T., and Kawaguchi, M. (2006). Shoot-applied MeJA suppresses root nodulation in Lotus japonicus. Plant Cell Physiol. 47, 176-180. doi: $10.1093 / \mathrm{pcp} / \mathrm{pci} 222$

Nam, K., and Yoshihara, T. (2008). Bioorganic chemistry of the induction of potato tuber formation: a review. Fruit Veg. Cereal Sci. Biotech. 2, 69-81.

Naoi, K., and Hashimoto, T. (2004). A semi dominant mutation in an Arabidopsis mitogen-activated protein kinase phosphatase-like gene compromises cortical microtubule organization. Plant Cell 16, 1841-1853. doi: 10.1105/tpc. 021865

Norastehnia, A., Sajedi, R. H., and Nojavan-Asghari, M. (2007). Inhibitory effects of methyl jasmonate on seed germination in maize (Zea mays): effect on $\alpha$-amylase activity and ethylene production. Gen. Appl. Plant Physiol. 33, 13-23.

Okamoto, H., Göbel, C., Capper, R. G., Saunders, N., Feussner, I., and Knight, M. R. (2009). The $\alpha$-subunit of the heterotrimeric G-protein affects jasmonate responses in Arabidopsis thaliana. J. Exp. Bot. 60, 1991-2003. doi: 10.1093/jxb/erp060

Oldroyd, G. E., and Downie, J. A. (2006). Nuclear calcium changes at the core of symbiosis signalling. Curr. Opin. Plant Biol. 9, 351-357. doi: 10.1016/j.pbi.2006.05.003 
Ortiz-Masia, D., Perez-Amador, M. A., Carbonell, J., and Marcote, M. J. (2007). Diverse stress signals activate the C1 subgroup MAP kinases of Arabidopsis. FEBS Lett. 581, 1834-1840. doi: 10.1016/j.febslet.2007.03.075

Orvar, B. L., Mcpherson, J., and Ellis, B. E. (1997). Pre-activating wounding response in tobacco prior to high-level ozone exposure prevents necrotic injury. Plant J. 11, 203-212. doi: 10.1046/j.1365-313X.1997.11020203.x

Ozturk, B., Ozkan, Y., and Yildiz, K. (2014). Methyl jasmonate treatments influence bioactive compounds and red peel color development of Braeburn apple. Turk. J. Agric. For. 38, 688-699. doi: 10.3906/tar-1312-43

Pauwels, L., Inze, D., and Goossens, A. (2009). Jasmonate-inducible gene: what does it mean? Trends Plant Sci. 14, 87-91. doi: 10.1016/j.tplants.2008.11.005

Pelacho, A. M., and Mingo-Castel, A. M. (1991). Jasmonic acid induces tuberization of potato stolons cultured in vitro. Plant Physiol. 97, 1253-1255. doi: 10.1104/pp.97.3.1253

Petersen, M., Brodersen, P., Naested, H., Andreasson, E., Lindhart, U., Johansen, B., et al. (2000). Arabidopsis map kinase 4 negatively regulates systemic acquired resistance. Cell 103, 1111-1120. doi: 10.1016/S0092-8674(00)00213-0

Pieterse, C. M. J., van der Does, D., Zamioudis, C., Leon-Reyes, A., and van Wees, S. C. (2012). Hormonal modulation of plant immunity. Annu. Rev. Cell Dev. Biol. 28, 1-33. doi: 10.1146/annurev-cellbio-092910-154055

Pieterse, C. M. J., Van Wees, S. C. M., Ton, J., Vanpelt, J. A., and Van Loon, L. C. (2002). Signalling in rhizobecteria-induced systematic resistance in Arabidopsis thaliana. Plant Biol. 4, 535-544. doi: 10.1055/s-2002-35441

Pirbalouti, A. G., Mirbagheri, H., Hamedi, B., and Rahimi, E. (2014). Antibacterial activity of the essential oils of myrtle leaves against Erysipelothrix rhusiopathiae. Asian Pac. J. Trop. Biomed. 4, 505-509. doi: 10.12980/APJTB.4.2014B1168

Preston, C. A., Laue, G., and Baldwin, I. T. (2004). Plant-plant signaling: application of trans- or cis-methyl jasmonates equivalent to sagebrush releases does not elicit direct defenses in native tobacco. J. Chem. Ecol. 30, 2193-2214. doi: 10.1023/B:JOEC.0000048783.64264.2a

Radhika, V., Kost, C., Boland, W., and Heil, M. (2010a). The role of jasmonates in floral nectar secretion. PLoS ONE 5:e9265. doi: 10.1371/journal.pone.0009265

Radhika, V., Kost, C., Mithöfer, A., and Boland, W. (2010b). Regulation of extra floral nectar secretion by jasmonates in lima bean is light dependent. Proc. Natl. Acad. Sci. U.S.A. 107, 17228-17233. doi: 10.1073/pnas.1009007107

Ranjan, R., and Lewak, S. (1992). Jasmonic acid promotes germination and lipase activity in non-stratified apple embryos. Physiol. Plant. 86, 335-339. doi: 10.1034/j.1399-3054.1992.860222.x

Rao, M. V., Lee, H., Creelman, R. A., Mullet, J. E., and Davis, K. R. (2000). Jasmonic acid signaling modulates ozone-induced hypersensitive cell death. Plant Cell 12, 1633-1646. doi: 10.1105/tpc.12.9.1633

Reid, D. E., Heckmann, A. B., Novák, O., Kelly, S., and Stougaard, J. (2016). CYTOKININ OXIDASE/DEHYDROGENASE3 maintains cytokinin homeostasis during root and nodule development in Lotus japonicus. Plant Physiol. 170, 1060-1074. doi: 10.1104/pp.15.00650

Reinbothe, C., Springer, A., Samol, I., and Reinbothe, S. (2009). Plant oxylipins: role of jasmonic acid during programmed cell death, defence and leaf senescence. FEBS J. 276, 4666-4681. doi: 10.1111/j.1742-4658.2009.07193.x

Riemann, M., Dhakarey, R., Hazman, M., Miro, B., Kohli, A., and Nick, P. (2015). Exploring jasmonates in the hormonal network of drought and salinity responses. Front. Plant Sci. 6:1077. doi: 10.3389/fpls.2015.01077

Robson, F., Okamoto, H., Patrick, E., Harris, S. R., Wasternack, C., Brearley, C., et al. (2010). Jasmonate and phytochrome a signaling in Arabidopsis wound and shade responses are integrated through JAZ1 stability. Plant Cell 22, 1143-1160. doi: $10.1105 /$ tpc.109.067728

Rohwer, C. L., and Erwin, J. E. (2008). Horticultural applications of jasmonates: a review. J. Hortic. Sci. Biotechnol. 83, 283-304. doi: 10.1016/j.biotechadv.2013.09.009

Rosahl, S., and Feussner, I. (2005). "Oxylipins" in Plant Lipids: Biology, Utilization, and Manipulation, ed. D. J. Murphy (Oxford: Blackwell Publishing), 329-354.

Santino, A., Taurino, M., De Domenico, S., Bonsegna, S., Poltronieri, P., Pastor, V., et al. (2013). Jasmonate signalling in plant defense response to multiple abiotic stresses. Plant Cell Rep. 32, 1085-1098. doi: 10.1007/s00299-013-1441-2

Sasaki, Y., Asamizu, E., Shibata, D., Nakamura, Y., Kaneko, T., Awai, K., et al. (2001). Monitoring of methyl jasmonate-responsive genes in Arabidopsis by cDNA macroarray: self activation of jasmonic acid biosynthesis and crosstalk with other phytohormone signaling pathways. DNA Res. 88, 153-161. doi: $10.1093 /$ dnares/8.4.153
Schaller, A., and Stintzi, A. (2009). Enzymes in jasmonate biosynthesisstructure, function, regulation. Phytochemistry 70, 1532-1538. doi: 10.1016/j.phytochem.2009.07.032

Schaller, M. (2011). The behavioral immune system and the psychology of human sociality. Philos. Trans. R. Soc. B Biol. Sci. 366, 3418-3426. doi: 10.1098/rstb.2011.0029

Schmelz, E. A., Grebenok, R. J., Ohnmeiss, T. E., and Bowers, W. S. (2002). Interactions between Spinacia oleracea and Bradysia impatiens: a role for phytoecdysteriods. Arch. Insect Biochem. Physiol. 51, 204-221. doi: 10.1002/arch.10062

Schommer, C., Palatnik, J. F., Aggarwal, P., Chetelat, A., Cubas, P., Farmer, E. E., et al. (2008). Control of jasmonate biosynthesis and senescence by miR319 targets. PLoS Biol. 6:e230. doi: 10.1371/journal.pbio.0060230

Schweighofer, A., Kazanaviciute, V., Scheikl, E., Teige, M., Doczi, R., Hirt, H., et al. (2007). The PP2C-type phosphatase AP2C1, which negatively regulates MPK4 and MPK6, modulates innate immunity, jasmonic acid, and ethylene levels in Arabidopsis. Plant Cell 19, 2213-2224. doi: 10.1105/tpc.106. 049585

Schweizer, P., Buchala, A., Silverman, P., Seskar, M., Raskin, I., and Métraux, J. P. (1997). Jasmonate-inducible genes are activated in rice by pathogen attack without a concomitant increase in endogenous jasmonic acid levels. Plant Physiol. 114, 79-88.

Seltmann, M. A., Stingl, N. E., Lautenschlaeger, J. K., Krischke, M., Mueller, M. J., and Berger, S. (2010). Differential impact of lipoxygenase and jasmonates on natural and stress-induced senescence in Arabidopsis. Plant Physiol. 152, 1940-1950. doi: 10.1104/pp.110.153114

Seo, H. S., Song, J. T., Cheong, J. J., Lee, Y. H., Lee, Y. W., Hwang, I., et al. (2001). Jasmonic acid carboxyl methyl transferase: a key enzyme for jasmonateregulated plant response. Proc. Natl. Acad. Sci. U.S.A. 98, 4788-4793. doi: 10.1073/pnas.081557298

Seo, S., Okamoto, M., Seto, H., Ishizuka, K., Sano, H., and Ohashi, Y. (1995). Tobacco MAP kinase: a possible mediator in wound signal transduction pathways. Science 270, 1988-1992. doi: 10.1126/science.270. 5244.1988

Seto, Y., Hamada, S., Ito, H., Masuta, C., Matsui, H., Nabeta, K., et al. (2011). Tobacco salicylic acid glucosyltransferase is active toward tuberonic acid (12-hydroxyjasmonic acid) and is induced by mechanical wounding stress. Biosci. Biotechnol. Biochem. 75, 2316-2320. doi: 10.1271/bbb. 110454

Shafiq, S., Akram, N. A., Ashraf, M., and Arshad, A. (2014). Synergistic effects of drought and ascorbic acid on growth, mineral nutrients and oxidative defense system in canola (Brassica napus L.) plants. Acta Physiol. Plant. 36, 1539-1553. doi: $10.1007 / \mathrm{s} 11738-014-1530-\mathrm{z}$

Shigeyama, T., Tominaga, A., Arima, S., Sakai, T., Inada, S., Jikumaru, Y., et al. (2012). Additional cause for reduced JA-Ile in the root of a Lotus japonicus phyB mutant. Plant Signal. Behav. 7, 746-748. doi: 10.4161/psb.20407

Soares, A. M., Souza, T. F., Jacinto, T., and Machado, O. L. T. (2010). Effect of methyl jasmonate on antioxidative enzyme activities and on the contents of ROS and $\mathrm{H}_{2} \mathrm{O}_{2}$ in Ricinus communis leaves. Braz. J. Plant Physiol. 22, 151-158. doi: 10.1590/S1677-04202010000300001

Sohn, H. B., Lee, H. Y., Seo, J. S., Jung, C., Jeon, J. H., Kim, J. H., et al. (2011). Overexpression of jasmonic acid carboxyl methyltransferase increases tuber yield and size in transgenic potato. Plant Biotechnol. Rep. 5, 27-34. doi: 10.1007/s11816-010-0153-0

Staswick, P. E. (1989). Developmental regulation and the influence of plant sinks on vegetative storage protein gene expression in soybean leaves. Plant Physiol. 89, 309-315. doi: 10.1104/pp.89.1.309

Staswick, P. E. (1994). Storage proteins of vegetative plant tissues. Annu. Rev. Plant Physiol. Plant Mol. Biol. 45, 303-322. doi: 10.1146/annurev.pp.45.060194.001511

Staswick, P. E. (2008). JAZing up jasmonate signaling. Trends Plant Sci. 13, 66-71. doi: 10.1016/j.tplants.2007.11.011

Staswick, P. E., and Tiryaki, I. (2004). The oxylipin signal jasmonic acid is activated by an enzyme that conjugates it to isoleucine in Arabidopsis. Plant Cell 16, 2117-2127. doi: 10.1105/tpc.104.023549

Stintzi, A., and Browse, J. (2000). The Arabidopsis male-sterile mutant, opr3, lacks the 12-oxophytodienoic acid reductase required for jasmonates synthesis. Proc. Nat. Acad. Sci. U.S.A. 97, 10625-10630. doi: 10.1073/pnas.190264497 
Stougaard, J. (2000). Regulators and regulation of legume root nodule development. Plant Physiol. 124, 531-540. doi: 10.1104/pp.124.2.531

Sua, M., Li, X. F., Ma, X. Y., Peng, X. J., Zhao, A. G., Cheng, L. Q., et al. (2011). Cloning two P5CS genes from bioenergy sorghum and their expression profiles under abiotic stresses and MeJA treatment. Plant Sci. 181, 652-659. doi: 10.1016/j.plantsci.2011.03.002

Sun, J., Cardoza, V., Mitchell, D. M., Bright, L., Oldroyd, G., and Harris, J. M. (2006). Crosstalk between jasmonic acid, ethylene and Nod factor signaling allows integration of diverse inputs for regulation of nodulation. Plant J. 46, 961-970. doi: 10.1111/j.1365-313X.2006.02751.x

Suza, W. P., Avila, C. A., Carruthers, K., Kulkarni, S., Goggin, F. L., and Lorence, A. (2010). Exploring the impact of wounding and jasmonates on ascorbate metabolism. Plant Physiol. Biochem. 48, 337-350. doi: 10.1016/j.plaphy.2010.02.004

Takahashi, F., Yoshida, R., Ichimura, K., Mizoguchi, T., Seo, S., Yonezawa, M., et al. (2007). The mitogen activated protein kinase cascade MKK3-MPK6 is an important part of the jasmonate signal transduction pathway in Arabidopsis. Plant Cell 19, 805-818. doi: 10.1105/tpc.106.046581

Thaler, J. S., Stout, M. J., Karban, R., and Duffey, S. S. (2001). Jasmonate-mediated induced plant resistance affects a community of herbivores. Ecol. Entomol. 26, 312-324. doi: 10.1046/j.1365-2311.2001.00324.x

Thines, B., Katsir, L., Melotto, M., Niu, Y., Mandaokar, A., Liu, G., et al. (2007). JAZ repressor proteins are targets of the SCF (COI1) complex during jasmonate signalling. Nature 448, 661-665. doi: 10.1038/nature05960

Tirichine, L., Sandal, N., Madsen, L. H., Radutoiu, S., Albrektsen, A. S., Sato, S., et al. (2007). A gain-of-function mutation in a cytokinin receptor triggers spontaneous root nodule organogenesis. Science 315, 104-107. doi: $10.1126 /$ science. 1132397

Trusov, Y., Rookes, J. E., Chakravorty, D., Armour, D., Schenk, P. M., and Botella, J. R. (2006). Heterotrimeric G proteins facilitate Arabidopsis resistance to necrotrophic pathogens and are involved in jasmonate signaling. Plant Physiol. 140, 210-220. doi: 10.1104/pp.105.069625

Tsukada, K., Takahashi, K., and Nabeta, K. (2010). Biosynthesis of jasmonic acid in a plant pathogenic fungus, Lasiodiplodia theobromae. Phytochemistry 71, 2019-2023. doi: 10.1016/j.phytochem.2010.09.013

Turner, J. G., Ellis, C., and Devoto, A. (2002). The jasmonate signal pathway. Plant Cell 14, 153-164.

Tuteja, N., Verma, S., Sahoo, R., Raveendar, S., and Reddy, I. (2012). Recent advances in development of marker free transgenic plants: regulation and biosafety concern. J. Biosci. 37, 167-197. doi: 10.1007/s12038-012-9187-5

Ueda, J., and Kato, J. (1980). Isolation and identification of a senescence-promoting substrate from wormwood (Artemisia absinthium L.). Plant Physiol. 66, 246249. doi: $10.1104 /$ pp.66.2.246

van der Graaff, E., Schwacke, R., Schneider, A., Deesimone, M., Flügge, U. I., and Kunze, R. (2006). Transcription analysis of Arabidopsis membrane transporters and hormone pathways during developmental and induced leaf senescence. Plant Physiol. 141, 776-792. doi: 10.1104/pp.106.079293

Vatanparast, G., Mirdehghan, H., Karimi, H., and Vazifeshenas, M. (2012). Foliar application of salicylic acid, methyl jasmonate and potassium sulfate on photosynthetic characteristics and fruit quality of pomegranate. Iran Agric. Res. 31, 23-34.

Vick, B. A., and Zimmerman, D. C. (1984). Biosynthesis of jasmonic acid by several plant species. Plant Physiol. 75, 458-461. doi: 10.1104/pp.75.2.458

Wakuta, S., Hamada, S., Ito, H., Matsuura, H., Nabeta, K., and Matsui, H. (2010). Identification of a $\beta$-glucosidase hydrolyzing tuberonic acid glucoside in rice (Oryza sativa L.). Phytochemistry 71, 1280-1288. doi: 10.1016/j.phytochem.2010.04.025

Wang, C. Y. (1999). Methyl jasmonate reduces water stress in strawberry. J. Plant Growth Regul. 18, 127-134. doi: 10.1007/PL00007060

Wang, C. Y., and Buta, J. G. (1994). Methyl jasmonate reduces chilling injury in Cucurbita pepo through its regulation of abscisic acid and polyamine levels. Environ. Exp. Bot. 34, 427-432. doi: 10.1016/0098-8472(94)90025-6

Wang, K., Jin, P., Cao, S., Shang, H., Yang, Z., and Zheng, Y. (2009). Methyl jasmonate reduces decay and enhances antioxidant capacity in Chinese bayberries. J. Agric. Food Chem. 57, 5809-5815. doi: 10.1021/jf900914a

Wasternack, C. (2007). Jasmonates: an update on biosynthesis, signal transduction and action in plant stress response, growth and development. Ann. Bot. 100, 681-697. doi: 10.1093/aob/mcm079
Wasternack, C., Goetz, S., Hellwege, A., Forner, S., Strnad, M., and Hause, B. (2012). Another JA/COI1-independent role of OPDA detected in tomato embryo development. Plant Signal. Behav. 7, 1349-1353. doi: $10.4161 / \mathrm{psb} .21551$

Wasternack, C., and Hause, B. (2002). "Jasmonates and octadecanoids - signals in plant stress response and development," in Progress in Nucleic Acid Research and Molecular Biology, ed. K. Moldave (New York, NY: Academic Press), $165-222$.

Wasternack, C., and Hause, B. (2013). Jasmonates: biosynthesis, perception, signal transduction and action in plant stress response, growth and development. An update to the 2007 review. Ann. Bot. 111, 1021-1058. doi: 10.1093/aob/ mct067

Wasternack, C., and Kombrink, E. (2010). Jasmonates: structural requirements for lipid-derived signals active in plant stress responses and development. ACS Chem. Biol. 5, 63-77.

Wei-Wei, J., Yan, W., Hui-hui, Z., Zhi-li, J., Peng, W., Xin, L., et al. (2011). Effects of foliar spraying methyl jasmonate on leaf chlorophyll fluorescence characteristics of flue-cured tobacco seedlings under drought and re-watering. Chin. J. Appl. Ecol. 22, 3157-3162.

Wittenbach, V. A. (1983). Purification and characterization of a soybean leaf storage glycoprotein. Plant Physiol. 73, 125-129. doi: 10.1104/pp.73.1.125

Wolucka, B. A., Goosens, A., and Inze, D. (2005). Methyl jasmonate stimulates the de novo biosynthesis of vitamin C in plant cell suspensions. J. Exp. Bot. 56, 2527-2538. doi: 10.1093/jxb/eri246

Xie, D. X., Feys, B. F., James, S., Nieto-Rostro, M., and Turner, J. G. (1998). COI1: an Arabidopsis gene required for jasmonate-regulated defense and fertility. Science 280, 1091-1094. doi: 10.1126/science.280.5366.1091

Xue, R., and Zhang, B. (2007). Increased endogenous methyl jasmonate altered leaf and root development in transgenic soybean plants. J. Genet. Genomics 34 , 339-346. doi: 10.1016/S1673-8527(07)60036-8

Yamane, H., Abe, H., and Takahashi, N. (1982). Jasmonic acid and methyl jasmonate in pollens and anthers of three Camellia species. Plant Cell Physiol. $23,1125-1127$.

Yan, Y., Borrego, E., and Kolomiets, M. V. (2013). "Jasmonate biosynthesis, perception and function in plant development and stress response," in Lipid Metabolism, Chap. 16, ed. R. V. Baez (Rijeka: InTech), 393-442.

Yan, Y., Stolz, S., Chételat, A., Reymond, P., Pagni, M., Dubugnon, L., et al. (2007). A downstream mediator in the growth repression limb of the jasmonate pathway. Plant Cell 19, 2470-2483. doi: 10.1105/tpc.107. 050708

Yoon, J. H., Rokem, A. S., Silver, M. A., Minzenberg, M. J., Ursu, S., Ragland, J. D., et al. (2009). Diminished orientation-specific surround suppression of visual processing in schizophrenia. Schizophr. Bull. 35, 1078-1084. doi: 10.1093/schbul/sbp064

Zebelo, S., Piorkowski, J., Disi, J., and Fadamiro, H. (2014). Secretions from the ventral eversible gland of Spodoptera exigua caterpillars activate defenserelated genes and induce emission of volatile organic compounds in tomato, Solanum lycopersicum. BMC Plant Biol. 14:140. doi: 10.1186/1471-222914-140

Zhang, L., Xi, D., Luo, L., Meng, F., Li, Y., Wu, C., et al. (2011). Cotton GhMPK2 is involved in multiple signaling pathways and mediates defense responses to pathogen infection and oxidative stress. FEBS J. 278, 1367-1378. doi: 10.1111/j.1742-4658.2011.08056.x

Zheljazkov, V. D., Astatkie, T., and Jeliazkova, E. (2013). Effect of foliar application of methyl jasmonate and extracts of juniper and sagebrush on essential oil yield and composition of 'Native' Spearmint. Hortic. Sci. 48, 462-465.

Conflict of Interest Statement: The authors declare that the research was conducted in the absence of any commercial or financial relationships that could be construed as a potential conflict of interest.

Copyright @ 2016 Ahmad, Rasool, Gul, Sheikh, Akram, Ashraf, Kazi and Gucel. This is an open-access article distributed under the terms of the Creative Commons Attribution License (CC BY). The use, distribution or reproduction in other forums is permitted, provided the original author(s) or licensor are credited and that the original publication in this journal is cited, in accordance with accepted academic practice. No use, distribution or reproduction is permitted which does not comply with these terms. 